\title{
QUEEN'S
UNIVERSITY
BELFAST
}

\section{Family Focused Practice in Mental Health Care: An Integrative Review}

Foster, K., Maybery, D., Reupert, A., Gladstone, B., Grant, A., Ruud, T., Falkov, A., \& Kowalenko, N. (2016). Family Focused Practice in Mental Health Care: An Integrative Review. Child and Youth Services, 37(2), 129155. https://doi.org/10.1080/0145935X.2016.1104048

\section{Published in:}

Child and Youth Services

\section{Document Version:}

Peer reviewed version

\section{Queen's University Belfast - Research Portal:}

Link to publication record in Queen's University Belfast Research Portal

\section{Publisher rights}

(C) 2015 Taylor \& Francis,

This is an Accepted Manuscript of an article published by Taylor \& Francis in Child \& Youth Services on 04 Nov 2015, available online: http://www.tandfonline.com/doi/abs/10.1080/0145935X.2016.1104048

\section{General rights}

Copyright for the publications made accessible via the Queen's University Belfast Research Portal is retained by the author(s) and / or other copyright owners and it is a condition of accessing these publications that users recognise and abide by the legal requirements associated with these rights.

\section{Take down policy}

The Research Portal is Queen's institutional repository that provides access to Queen's research output. Every effort has been made to ensure that content in the Research Portal does not infringe any person's rights, or applicable UK laws. If you discover content in the Research Portal that you believe breaches copyright or violates any law, please contact openaccess@qub.ac.uk. 


\title{
Family-focused practice in mental health care: an integrative review
}

\author{
Kim Foster RN, PhD, Darryl Maybery BA, BSc(Hons), PhD, Andrea Reupert \\ BA, DipEd, GradDipCounsPsych, PhD, Brenda Gladstone PhD, Anne Grant \\ BSc, Med, PhD, Torleif Ruud, Adrian Falkov MB, FRCPsych, FRANZCP \& Nick \\ Kowalenko BM BS. FRANZCP
}

To cite this article: Kim Foster RN, PhD, Darryl Maybery BA, BSc(Hons), PhD, Andrea Reupert BA, DipEd, GradDipCounsPsych, PhD, Brenda Gladstone PhD, Anne Grant BSc, Med, PhD, Torleif Ruud, Adrian Falkov MB, FRCPsych, FRANZCP \& Nick Kowalenko BM BS. FRANZCP (2015):

Family-focused practice in mental health care: an integrative review, Child \& Youth Services, DOI: 10.1080/0145935X.2016.1104048

To link to this article: http://dx.doi.org/10.1080/0145935X.2016.1104048

Accepted author version posted online: 04 Nov 2015.

Submit your article to this journal ¿

Џlll Article views: 14

View related articles $₫$

View Crossmark data ¿ 


\section{ACCEPTED MANUSCRIPT}

\section{Family-focused practice in mental health care: an integrative review}

\section{Kim Foster, RN, PhD (Corresponding author)}

Faculty of Health, University of Canberra

Locked Bag 1, University of Canberra

ACT 2601

AUSTRALIA

kim.foster@canberra.edu.au

Darryl Maybery, BA, BSc(Hons), PhD

Department of Rural and Indigenous Health, School of Rural Health

Monash University

3 Ollerton Avenue, Moe, 3825 Australia

darryl.maybery@monash.edu

\section{Andrea Reupert, BA, DipEd, GradDipCounsPsych, PhD}

Krongold Centre

Faculty of Education

Monash University, Clayton

3800 Victoria

Australia

andrea.reupert@monash.edu.au 


\title{
ACCEPTED MANUSCRIPT
}

\author{
Brenda Gladstone, PhD \\ Dalla Lana School of Public Health, \\ Community Health Systems Resource Group \\ The Hospital for Sick Children \\ University of Toronto \\ 555 University Ave., \\ Toronto, Ontario, Canada M5G 1X8 \\ Brenda.gladstone@sickkids.ca
}

Anne Grant, BSc, Med, PhD

School of Nursing and Midwifery,

Queens University, Belfast,

Northern Ireland

A.Grant@qub.ac.uk

\section{Torleif Ruud}

Akershus University Hospital, Division of Mental Health Services,

Box 1000, 1478 Lørenskog, Norway, and University of Oslo,

Institute of Clinical Medicine, Box 1171 Blindern, 0318 Oslo, Norway

torleif.ruud@medisin.uio.no 


\section{ACCEPTED MANUSCRIPT}

\section{Adrian Falkov, MB, FRCPsych, FRANZCP}

Redbank House CAMHS

Westmead Hospital

Institute Road, WESTMEAD

NSW 2145

Adrian.Falkov@ @ealth.nsw.gov.au

Nick Kowalenko, BM BS. FRANZCP

Discipline of Psychiatry, University of Sydney

CAMHS, Level 2

CHC, 2c Herbert St

ST. LEONARDS NSW 2065 AUSTRALIA

Nick.Kowalenko@health.nsw.gov.au

Family-focused practice in mental health care: an integrative review

\section{Highlights}

- In mental health services, family-focused practice is poorly defined concept

- An integrative review was conducted to synthesize evidence in this area

- Six core and inter-related family-focused practices were identified

- Family as defined by its members provides a basis for 'whole of family' care 


\title{
ACCEPTED MANUSCRIPT
}

\author{
ABSTRACT \\ While mental health services are increasingly encouraged to engage in family-focused practice, it \\ is a nebulous and poorly understood term. The aim of this paper was to examine and synthesize \\ evidence on the concept and scope of family-focused practice in adult and child and youth \\ mental health care settings. An integrative literature review method was used. Medline, \\ Embase, CINAHL, PsycInfo and Proquest electronic databases were systematically searched for \\ abstracts published in English between 1994-2014. Data were extracted and constant \\ comparative analysis conducted with 40 included articles. Family-focused practice was \\ conceptualised variously depending on who was included in the 'family', whether the focus was \\ family of origin or family of procreation, and the context of practice. As a finding of the review, \\ six core and inter-related family-focused practices were identified: family care planning and \\ goal-setting; liaison between families and services; instrumental, emotional and social support; \\ assessment; psychoeducation; and a coordinated system of care between families and services. \\ While family is a troubled concept, 'family' as defined by its members forms a basis for practice \\ that is oriented to providing a 'whole of family' approach to care. In order to strengthen family \\ members' wellbeing and improve their individual and collective outcomes, key principles and \\ practices of family-focused practice are recommended for clinicians and policy makers across \\ mental health settings.
}

Keywords: Integrative review; family-focused practice; child and adolescent; adult; mental health services 


\section{ACCEPTED MANUSCRIPT}

\section{Family-focused practice in mental health care: an integrative review}

\section{INTRODUCTION}

Mental illness impacts on more than the individual. Family members, including children, are all affected by a family member's mental illness. Increasingly, governments and service providers across countries are investing in a family-centred, collaborative model of practice (Nicholson et al., 2015). Family-focused practice (FFP) broadens the unit of care provision in mental health services from a narrow focus on the mental health consumer, to the wider family and caregiving system (Foster, O’Brien \& Korhonen, 2012). However, there is little consistency in how FFP is defined, and in particular, a lack of integrated knowledge on FFP in mental health services. The lack of conceptual clarity in FFP is also reflected in the terminology employed, where FFP is used interchangeably with 'family-oriented', 'family-sensitive' and 'familycentred'. It is important to note that FFP does not refer to 'family involvement'. Family involvement refers to how adult family members, generally parents, are engaged with organisations in managing an identified issue or concern for a child. Most commonly this is in regard to family involvement in children's learning in schools, although Modlin (2004) highlighted family involvement can include interventions such as parent support groups in children's residential programs.

In this review, FFP refers to how mental health clinicians (e.g. nurses, psychologists, social workers, doctors or occupational therapists) and mental health services respond to other family members when an adult or child has the identified mental health problem. In summary, there is a clear need to examine the concept of FFP across different mental health service contexts (adult and child inpatient or community), in order to provide a framework for clinical 


\section{ACCEPTED MANUSCRIPT}

practices between mental health service providers, mental health consumers and their families, and for the purposes of mental health policy and service evaluation.

The term family-focused practice (FFP) originated in the field of paediatrics in the 1950s, where parents campaigned to be included in the planning of their children's medical care (Jolley \& Shields, 2009). Accordingly, much of the work in FFP has been conducted in areas such as disability and chronic illness, where the client or consumer is the child (Hoagwood, 2005). In these healthcare fields, core FFP principles are related to placing the consumer and family at the centre of care decisions, respecting the cultural and linguistic traditions of the family, acknowledging that consumers and their families are experts on their own needs, and keeping the relationship between the professional team, consumer and family collaborative, respectful, open and honest (Dunst, Trivette \& Hornby, 2007; Mikkelsen \& Frederiksen, 2011). MacKean et al. (2012) reviewed similar concepts in child and adolescent mental health services but not adult settings. Using the term family-centred care (FCC), they found improved child and family management skill, increased stability of living situations and improved child and family health and wellbeing as a result of FCC. However, the same depth of research has not been conducted in relation to FFP across mental health services.

A paradigm shift from a traditional, individual model of mental health care toward FFP has slowly gained traction in mental health services over the past decade, as can be ascertained in policies across the US, Australia, Canada, Ireland, the UK and Norway (Nicholson et al., 2015). This has been promoted, at least in part, by repeated research which highlights the benefits of FFP for consumers and their family. In a meta-analysis of 25 studies, Pitschel-Walz, Leucht, Bauml, Kissling and Engel (2001) found that the relapse rate was reduced by 20 percent when 


\section{ACCEPTED MANUSCRIPT}

relatives of consumers with schizophrenia were involved in their treatment and care, compared to standard medication treatment. Similarly, Glynn, Cohen, Dixon and Niv (2006) found that FFP was effective in reducing exacerbations in schizophrenia, improving mediation compliance and reducing or eliminating substance abuse. FFP also delivers benefits to the family, with a reduction in subjective burden of care and increased levels of self-care and emotional role functioning (Glynn et al., 2006).

Nevertheless, how FFP within mental health services is conceptualised and subsequently practised is less clear. There are many components of FFP in mental health services documented in the literature but how these relate to each other and promote a consistent set of practice guidelines is currently not available. For example, the Centre for Addiction and Mental Health (2004, p. 3) include "treating clients and their families with dignity and respect" and "openly communicating with clients and families" while the Family Mental Health Alliance (2006) focuses on meeting families' needs, which includes providing education about mental illness and available community services and supports. While noting the proliferation of policies related to family focused practice in child services, Hoagwood (2005) argues that "there are remarkably few studies that have examined experimentally specific modalities of family-based services" ( $p$. 690). In adult services, and in reference to parents with mental health concerns and their children, there have been repeated studies that have highlighted the lack of definitional clarity and theoretical integration in respect to family inclusive practices (Maybery et al. 2014; Maybery, Goodyear \& Reupert, 2012; Maybery \& Reupert, 2006). While Dempsey and Keen (2008, p. 43) note that family centred care has had an important influence on mental health service philosophy 


\section{ACCEPTED MANUSCRIPT}

and orientation, the "family-centred field can best be described as being in an adolescent phase of development" in terms of providing a coherent service and practice delivery model.

The main feature of FFP in mental health services that is commonly presented involves psychoeducation, where information is provided to the family about the consumer's diagnosis, causes, treatment and progress (Lucksted, McFarlane, Downing, Dixon \& Adams, 2012). Psychoeducation may also provide an opportunity for family members to manage their stress levels and learn specific skills in helping their relative (Hoagwood, 2005). Others describe FFP in terms of a family member, typically the parent, working as a 'co-therapist' with the professional team, in making treatment and programming decisions for their relative (MacFarlane, 2011). Further elements of FFP include viewing families as a source of information about their relative to supplement assessment and inform treatment options, and acknowledging and responding to the family's caring role and/or how they cope. More recently, discussions of FFP have acknowledged the parenting role and responsibilities for many consumers and highlighted the needs of consumers' children (Reupert, Maybery \& Kowalenko, 2012).

Notwithstanding the benefits involved in FFP, there are a number of barriers associated with its uptake. Maybery and Reupert (2006) found that the mental health clinical workforce lack the skills and knowledge to engage effectively and work collaboratively with family members, with clinicians still believing that a consumer's mental health difficulties originated with family members. Another significant barrier is clarity around how FFP might be conceptualised, practised and evaluated (Foster et al., 2012). 


\section{ACCEPTED MANUSCRIPT}

While families are important for those with mental health problems (Reupert et al., 2012), there are very few theoretical or practice frameworks that show how families might be included across different mental health treatment settings. Although there are many ways that 'family' can be defined, we align ourselves to Osher and Osher's (2002) concept of family, where a family, and who is included in a family, is defined by its members. This definition acknowledges diverse family relationships that may not necessarily resemble a traditional nuclear family. Specifically for this review, we examine families of origin, the family a person is born into and where the family includes the parents of a mental health consumer (child or adult), as well as families of procreation or choice, where the family are the children/partner of the consumer, while also noting the inclusion of other family members (such as grandparents, caregivers, and so on).

How FFP might be conceptualised and subsequently practised may relate to the settings from which it is delivered (for example, child or adult mental health services) and similarly, whether the mental health consumer is a child or an adult. For example, how parents/caregivers are engaged and involved by clinicians in the treatment of their child may differ from how parents work with services for their adult offspring. The needs of these different family types may vary and this has potential implications for FFP and how it is operationalised. While the underlying principle of FFP in terms of working with and for families, rather than to families, appears to be consistent across child and adult contexts (Hoagwood, 2005; McFarlane, 2011), there is a notable lack of family-focused practice models driven by conceptual frameworks that may be reliably employed in both settings. Greater clarity on the concept of FFP and its practice in mental health settings will inform future measurement, audit and evaluation of FFP, provide 


\section{ACCEPTED MANUSCRIPT}

guidance on the scope of FFP, and inform professional development in the effective practice and provision of FFP.

\section{AIM}

The aim of this paper is to examine and synthesize evidence on the concept and scope of FFP in adult and child and youth mental health services in order to advance understanding and implementation of family-focused practice. The research questions framing this review are:

1. How is family-focused practice conceptualised and defined from a mental health perspective in adult as well as child and youth mental health service provision?

2. What are the family-focused practices in adult and child and youth mental health service provision?

\section{METHOD}

An integrative review method was employed. This approach uses systematic processes for literature searching and selection, and for data extraction and analysis. An integrative review method allows for inclusion of theoretical and empirical literature and is used for a range of review purposes including concept definition (Whittemore \& Knafl, 2005).

\section{Data Sources}

Medline, Embase, CINAHL, PsycInfo, and Proquest databases were searched for abstracts (see Table 1).

Insert Table 1 about here.

\section{Inclusion and exclusion criteria}

To gain an understanding of the development of FFP over time, peer-reviewed literature published between 1994 and 2014, including empirical, theoretical, and/or discussion papers 


\section{ACCEPTED MANUSCRIPT}

focusing on professional practices for children or adults with mental illness in child and youth, or adult mental health settings, were included. Literature reviews, book chapters, and grey literature were excluded. Papers that examined family therapy alone, or family-focused practice for other health conditions, or in other settings, e.g. schools, were excluded.

\section{Screening}

Titles and abstracts of 2123 records were reviewed independently by the first three authors against the inclusion/exclusion criteria. Full texts of retained articles were then read and screened, and consensus discussion resulted in 40 articles included for review (Figure 1).

\section{Insert Figure 1}

\section{Analysis}

Consistent with the integrative review method (Whittemore \& Knafl, 2005), data were initially extracted from the 40 articles into a matrix according to the review questions. Constant comparative analysis was used to categorise and group coded extracts, which were iteratively compared and contrasted within and across articles. Key concepts relevant to each question were collated and emergent patterns and themes identified (Patton, 2002). Key concepts and practices related to family-focused practice were also counted to gain an understanding of the contextual use and emphasis of content in the articles (Hseih \& Shannon, 2005). In the final process, data were synthesised into an integrated thematic summary of findings.

\section{FINDINGS}

The review included 40 articles; $* 20$ empirical research papers, $* 22$ discussion/opinion papers and four theoretical papers (*see Table 2; some papers provided both a discussion of FFP and empirical data). Findings are presented according to the two review questions. 


\section{ACCEPTED MANUSCRIPT}

\section{Insert Table 2}

\section{Concepts of family-focused practice in adult and child and youth mental healthcare}

Twenty-one of the 40 papers described family-focused practice within adult orientated mental health services (hereafter referred to as Adult MH); 19 referred to child or youth orientated mental health services (hereafter referred to as Child $\mathrm{MH}$ ). The majority of Adult $\mathrm{MH}$ publications referred to family of procreation or choice, where a parent had mental illness $(\mathrm{n}=$ 16); the remainder primarily focused on family of origin. In contrast, all but one of the Child MH papers adopted a family of origin perspective. Two adult orientated papers included both family of origin and family of procreation (Mottaghipour \& Bickerton, 2005; Schmidt \& Monaghan, 2012); one youth orientated service included both family types (Miklowitz, Biuckians \& Richards, 2006). However, while some Child MH papers mentioned parental mental illnesses (e.g., Miklowitz et al., 2006), the primary focus was on the child at risk of, or diagnosed with, a mental illness or behavioural disorder. The majority of Adult MH papers were from Australia $(n=8 / 21)$, USA $(n=4 / 21)$ and Finland $(n=3 / 21)$ with one paper coming from a non-western country (Samoa; Enoka et al., 2013). The majority of Child MH literature originated in the USA $(n=14 / 19)$.

\section{Terms used to describe FFP}

There was a plethora of ways to describe FFP, often used interchangeably. While not always clear, some referred to programs ( $\mathrm{n}=7$; for example, the family-focused case management program [FFCM; Aubry et al., 2000]), approaches ( $\mathrm{n}=2$; for example, a family-focused approach; Foster et al., 2012), as an intervention framework for working with clients and their 


\section{ACCEPTED MANUSCRIPT}

families ( $\mathrm{n}=6$, see for example, Beardslee's intervention for families where a parent has depression), as a service ( $\mathrm{n}=5$, e.g. Gross $\&$ Goldin, 2008) or as a model for how services might work with families ( $\mathrm{n}=9$, for example, Mottaghipour \& Bickerton's 2005, pyramid of family care). Some terms were used synonymously with FFP; family centred (10/40), family sensitive (4/40), family orientated ( $n=3)$ and family inclusive $(n=2)$. These terms recognised the family's pivotal caring role and a concomitant requirement that family be included in services. Nevertheless, there was a lack of clear consensus about the terms and how they were used to describe and define FFP in Adult and Child MH (see Table 2).

\section{Family defined}

Integral to the concept of FFP is how 'family' is defined. While a range of definitions of 'family' appeared in the Adult MH literature, there were significant differences in how this was interpreted; this also differed depending on whether the paper assumed a family of procreation/choice or origin perspective. For example, family of origin included definitions of the family restricted to consumers' adult family members (individuals 18 years or older) and who were acknowledged as the primary carers (Aubry et al., 2000; Dausch et al., 2012; Enoka et al., 2013; Mullen, Murray \& Happell, 2002). Typically other members were excluded from the FFP focus including dependent children though there was an exception; from a Samoan perspective, Enoka et al., (2013), included siblings, partners and extended family members in their description of family.

Conversely, when the focus was on the family of procreation within adult MH services, children were included in discussions of FFP (e.g. Cowling \& Garrett, 2009; Devlin \& O’Brien, 


\section{ACCEPTED MANUSCRIPT}

1999; Foster et al., 2012; Heitmann, Schmuhl, Reinisch \& Bauer, 2012; Hinden, Biebel, Nicholson \& Mehnert, 2005; Houlihan, Sharek \& Higgins, 2013; Jessop \& de Bondt, 2012;

Korhonen, Vehviläinen-Julkunen \& Pietilä, 2008; Maddocks, Johnson, Wright \& Stickley, 2010; Maybery, Goodyear, O'Hanlon, Cuff \& Reupert, 2014). Some authors who incorporated both family of origin and family of procreation included children and other family members (Mottaghipour \& Bickerton, 2005; Schmidt \& Monaghan, 2012). Overall, those with a family of procreation perspective referred to varying family configurations and considered the needs of all family members, including children, partners and spouses, grandparents, and significant others. This was irrespective of whether family members were caring for or were being cared by the consumer.

In the Child MH literature the 'family' was described as a 'system', or an 'ecology of the family' (Lee et al., 2009; Malysiak, 1997). 'Family' also referred to individual members (Lepage, 2005), including siblings (e.g. Furniss et al., 2013; Gross \& Goldin, 2008; Young \& Fristad, 2007), or siblings and parents (Kilmer, Cook \& Palamaro Munsell, 2010). 'Family' also incorporated 'non-professionals' as part of an extended, non-hierarchical collaborative (plusfamily) team partnership model that 'wraps around' the child identified as needing services (e.g. Handron, Dosser, McCammon \& Powell, 1998). This support was considered informal and provided by significant others identified as important to the family and who acted as unpaid caregivers (e.g. friends, neighbours, coaches) (Kilmer et al., 2010). Allen and Petr (1998) argued that family included whomever the family designates as being in the family. 


\section{ACCEPTED MANUSCRIPT}

\section{Family-focused Practice conceptualisations}

The concept of FFP in Child MH literature links definitions of 'family' to the mental health care context (e.g. the home or community) and the practice intentions of that environment or anticipated mode of service delivery. For example, Child MH publications from the USA described children considered at risk of 'out-of-home placement'. 'Home' was significant in conceptualizing FFP because 'home based' and 'family-focused' treatment programs described the least restrictive care setting as optimal; FFP occurred in the community (or home) because it was closest to the family's natural supports (e.g. Woolston, 2007). The intention was to avoid an ever-increasing continuum of restrictive (and more costly) environments in which children might be hospitalized or placed in residential care (e.g. Bartlett, Herrick \& Greninger, 2006; Lee et al., 2009; Woolston, 2007), and services were directed toward 'preserving' or keeping the family together (Mosier et al., 2001). A day hospital treatment setting for 'psychiatrically ill' infants, toddlers and pre-school children that provided a continuum of flexible care including community and in-patient settings was held to combine the best of both care contexts (Furniss et al., 2013).

An emphasis on family support in the family of origin literature was predicated on the goal of reducing primary caregivers' negative impact on consumers' wellbeing, and promoting

their capacity to help consumer recovery (Aubry et al., 2000; Dausch et al., 2012). While family involvement was recognised to reduce family members' distress, the ultimate aim of family inclusion was to help the consumer (Mottaghipour \& Bickerton, 2005; Schmidt \& Monaghan, 2012).

There were a number of principles that underpinned the range of terms used to conceptualize FFP and the notion of 'family', which are shaped by, and shape, their translation in 


\section{ACCEPTED MANUSCRIPT}

practice (Table 2). For instance, the Adult MH papers highlighted the importance of familial and community-based care that is individualised, holistic, flexible, transparent, responsive, preventative (e.g., Maybery et al., 2012) and culturally sensitive (Enoka et al., 2013). Thirteen papers explicitly referred to a strengths-based approach that fosters family self-esteem and efficacy as well as resilience (e.g. Foster et al., 2012; Hinden et al., 2005). A number $(\mathrm{n}=6)$ emphasised engaging families in the recovery process (e.g. Mullen et al., 2002), and promoting family resilience through collaborative partnerships (Mottaghipour \& Bickerton, 2005). From a family of procreation perspective, some authors proposed that children could be indirectly supported through enhancing parents' resilience and capacity to cope (Korhonen et al., 2010a); although most argued that children's needs should be directly addressed by Adult MH services (Cowling \& Garrett, 2009; Heitmann et al., 2012; Hinden et al., 2005; Maddocks et al. 2010; Nicholson, 2007).

\section{Family-focused practices in adult and child and youth mental healthcare}

In addition to a conceptualisation of FFP, the papers were examined for clinicians' familyfocused practices. As a result of analysis, six core and inter-related mental health practices with consumers and their family, across child and adult services, were identified:

1. Family care planning and goal setting;

2. Liaison between families and services including family advocacy;

3. Instrumental, emotional and social support;

4. Assessment of family members and family functioning;

5. Psychoeducation; 


\section{ACCEPTED MANUSCRIPT}

6. A coordinated system of care (e.g. wraparound, family collaboration, partnership) between family members and services. See Table 3 for further detail.

\section{Insert Table 3 about here}

It is important to recognise that many of these practices are not mutually exclusive. For instance, there was overlap between liaising with other services, advocating for families and providing a coordinated system of care as might be required in a wraparound service for families. Also indicating an overlap amongst practices, Maddocks et al. (2010) defined support in terms of “being present during clients' visits to their children, advocating for clients and providing reassurance" (p. 677). Nonetheless, discrete actions can be identified as distinct dimensions of FFP. The most commonly reported practices were providing instrumental, emotional or social support to the family (21/40) and delivering a coordinated system of care (22/40). The remaining four practices were reported almost equally (between 15 and 17 times). Two practices were more commonly reported in Child MH papers; undertake care planning and goal setting with families (ten times compared to four) and provide a coordinated system of care between and within family members and services (13 times compared to 9 ). There was little/no different amongst other practices between the two settings.

\section{Family care planning and goal-setting}

The practice of care planning and goal setting with families commonly aimed to mobilise a family's resources, including support networks (15/40 papers). While this involved planning for future possible crises, it was more commonly employed to identify what is important for the family in the short and long term. Goals for the family were collaboratively established between clinicians and family members and grounded within a strengths-based approach. The plans were 


\section{ACCEPTED MANUSCRIPT}

a means of managing relationships outside of the family including other family members as well as services, thereby meeting the consumer's treatment goals but also the needs of family members. Nicholson (2007) described the importance of setting basic goals for parents with a mental illness, such as creating a safe environment for their children and getting their children to school with the ultimate long term goal of skills building and recovery. Acknowledging the importance of being able to respond to 24 hour family crises, Hinden et al. (2005) also noted the need to collaboratively establish long term targeted outcomes with families that might, for instance, include improved housing, increased employment and decreased hospitalization.

\section{Liaison between family and services}

Another commonly reported FFP practice was liaising between the family and other services or informal networks $(n=17 / 40)$. This also occurred within the one agency; Cowling and Garrett (2009) described how one clinician worked with a parent with a mental illness while another clinician from the same agency worked with the child. Lepage (2005) presented a collaborative approach amongst the clinicians within the one service as well as with other services. Foster et al. (2012) urged clinicians to encourage children and parents to engage with others in their community and liaise with other services as required for the families they worked with, for example, housing organisations. Lee et al. (2009) argued that effective treatment must include "coordination and collaboration among the diverse organizations providing services to the child and the family" (p. 397). Extending this practice, Aubry et al. (2000) suggested that liaison between services involved advocating for appropriate and timely services. Similarly, Devlin and O'Brien (1999) argued that clinicians needed to advocate for parents with a mental illness when dealing with child protective services. Gopalan and colleagues (2014) described the 


\section{ACCEPTED MANUSCRIPT}

employment of parent advocates who themselves had previously navigated through the Child MH system and "who could work with families in a different way" (p. 90).

\section{Instrumental, emotional \& social support}

Instrumental support included referring a family member to appropriate services and organising practical support for example, transport or child-care (Reupert \& Maybery, 2014). Emotional support involved providing empathy and compassion e.g., Bartlett et al. (2006) asserted that clinicians need to "provide emotional support to family members so that they can nurture each other, survive periods of crisis and flourish" (p. 597). Aubry et al. (2000) indicated that 25 percent of the clinician's time was spent providing support which involved "assisting with family relationships, especially those involving the member with severe mental illness, discussing and mediating family difficulties, and helping families to cope with stress" (2000, p. 71). Social support involved broadening a family and consumer's social networks (for example, Foster et al., 2012). Several papers described embedding support within service or treatment (e.g. Gopalan, et al., 2014; Lee et al., 2009; Sin, Moone \& Newell, 2007). Sometimes support aimed to empower the consumer or family, for example, the clinician supported parents to solve their own problems, rather than rely on professionals (Lee et al., 2009).

\section{Assessment of family members and family functioning}

The assessment of family members centred on 'initial' and/or 'ongoing' assessment practices. The first involved identifying the presence of family (e.g. asking a consumer whether he or she had children at intake, see Foster et al., 2012) as well as assessing the needs of each family member (e.g., Korhonen et al., 2008). Assessment in this instance involved identifying individual and family strengths and/or deficits and the impact the mental illness on family 


\section{ACCEPTED MANUSCRIPT}

members, especially children (Cowling \& Garrett, 2009). Maybery et al. (2014) suggested that that all clinicians who have contact with parents with mental health challenges should have the skills to assess the impact of the illness on children. Other papers referred more generally to assessment practices for example, Dausch et al. (2012) suggested that FFP involved the following assessment domains; the consumer's diagnosis, the family and consumer's motivation for services, level of functioning/distress, goals and needs, role of the illness, subjective burden and the presence of practical issues.

Papers also included 'ongoing' assessment for determining families' changing needs over time, rather than a static, 'one off' often crisis-driven assessment (see for example Reupert \& Maybery, 2014). Mottaghipour and Bickerton (2005) discussed this in terms of a "reassessment of needs" (p. 6). In Child MH, such an approach was consistent with a developmental approach with children. This also acknowledged that parents need to be involved in assessing the child's problems over time (Bartlett et al., 2006).

\section{Psychoeducation for family}

Psychoeducation was a commonly mentioned family-focused practice (17/40) and involved a clinician who "teaches the family about [consumer] adolescent [disorder], encourages the [consumer] adolescent to chart his or her mood, provides information about risk and protective factors, such as how psychosocial factors can affect the course of the illness" (Young \& Fristad, 2007, p.158). Mullen et al. (as cited in Lepage, 2005, p. 89) note that "families of psychotic youth have a clear desire for information on what is happening... and for clinical guidance on how to best care for the psychotic person." Psychoeducational approaches ranged from awareness raising and general information about the disorder, treatment options and 


\section{ACCEPTED MANUSCRIPT}

information on services, through to specific manualised approaches for families (such as Beardslee's 2007 psychoeducation program for parents with depression and their children). Psychoeducation was found to delay relapse, improve family functioning, child wellbeing, communication, coping, and medication adherence, and assist family members to understand and cope with consumers' mental health problems (Beardslee et al., 2007; Miklowitz et al., 2006).

\section{Coordinated system of care for family}

Many papers (22/40) described a coordinated system of care, usually focused on a multidisciplinary team approach, which incorporated the family as a key entity within the team, who played a key role in assessment and intervention planning and delivery. Initiatives ranged from 'Wraparound' programs (Handron et al., 1998) to state-wide implementations of a coordinated system of care (Gopalan et al., 2014). These programs were commonly child-centred approaches with an emphasis on family members being active participants in the care of the child. Others described 'Wraparound' as the 'Wave of the Future' (Handron et al., 1998) based on a child-centred team approach that involves parents, the child, teacher, therapist, service coordinator, neighbours, friends, extended family doctor or nurse, and potentially social workers and others.

Family members were a key part of this coordinated team approach. This occurred in in adult MH services, "relatives are important to, connected with, and involved in the lives of persons with psychiatric illness, and family involvement is a vital aspect of recovery-oriented comprehensive care" (Dausch et al., 2012, p.7) and child MH services. For example, Lepage (2005, p. 92) argued that the treatment team consists of "the person with the mental illness, the family and clinicians". She continued by indicating that the family "provides the psychiatric 


\section{ACCEPTED MANUSCRIPT}

team with pertinent information regarding their loved one...[and assists] in assessment, treatment, recovery and relapse prevention" (p. 92).

\section{DISCUSSION}

This review sought to identify how family-focused practice (FFP) was conceptualised and practised in adult and child and youth mental health services. While FFP is reasonably developed in healthcare fields such as paediatrics, it has not been rigorously examined across adult and child and youth mental health services (Hoagwood, 2005; Maybery \& Reupert, 2006; McFarlane, 2011). As such, the review comprises an essential first step in interrogating familyfocused concepts and practices in mental health. Given the growing evidence base for child and adult family interventions across service settings and diagnostic groups (Glynn et al., 2006), as well as treatment recommendations (e.g. by the National Institute for Clinical Excellence in the UK 2009), it is timely to provide a conceptual analysis and description of pragmatic initiatives and practice in mental health settings, as a basis for greater rigor in policy development and practice.

The review found that FFP was conceptualised variously according who the 'family' consisted of, and more specifically whether the focus was family of origin or family of procreation or choice, and the context of practice. The problem with lack of conceptual clarity in FFP is that care for families is inconsistent, and family programs and interventions were not founded on comparable principles. 'Family' is a key dimension of the FFP concept and its definition is integral to its practice application. The historical review by Allen and Petr (1998), in particular, demonstrated the significance of defining “'the family' for conceptualizing FFP and that the concept of 'family' is historically, culturally and theoretically contingent. 


\section{ACCEPTED MANUSCRIPT}

A key finding from the review was that there are outdated assumptions which ignore temporal and cultural influences and changes in thinking about 'family'. These assumptions led to descriptions of the practice of family as being about a parent, sometimes a parent-child dyad, and often, the mother, who was assumed to be the primary caretaker. This finding needs to be considered in light of the family of origin and family of procreation or choice constructs, and raises several questions regarding models and practice contexts. If 'family' is viewed through only one lens, then the needs of only some family members are emphasised or addressed in practice. For services using a family of origin model (primarily child and youth services), for example, what could be learned from a family of procreation or choice model (primarily adult services) about envisioning the whole family differently in respect to FFP? This could, for instance, include viewing children as 'carers' as well as 'consumers' (Gladstone, McKeever, Seeman \& Boydell, 2014). The question is whether we can, or should, construct a single concept or framework for FFP in clinical practice, policy and evaluation for both settings.

While family is a troubled concept in the literature, 'family' as defined by its members (Osher \& Osher, 2002) forms a basis for practice that is oriented to providing a 'whole of family' approach to care, including adult family members, children, grandparents, extended family and other significant others, and in so doing helps to prevent transmission of mental illness between family members. The 'whole of family' focus can be understood as a means for FFP as a form of preventative intervention, in order to specifically address the impact of intergenerational impact mental illness from parents to children. Aligning ourselves to this concept could go some way to dealing with outdated and restrictive notions of the family. However it needs to be acknowledged that children and young people have differential access to the power and resources to define 


\section{ACCEPTED MANUSCRIPT}

themselves as family members in medical contexts (Gladstone et al., 2014). Further, this approach raises questions for FFP in terms of how we involve all members of the family and at the same time not subsume individual members, or individual roles within the family, so that members are disenfranchised as 'family' in significant ways.

The majority of Adult MH papers in the review were from Australia (8/21 papers) and the USA (4/21), while the majority of Child MH literature originated in the USA (14/19). This result raises contextual issues regarding mental health policy initiatives, funding priorities, and cultural conceptualisations and subsequent practices of FFP in mental health services. Nicholson et al. (2015) noted the absence of national policy setting or initiatives for children of parents with mental illness in the USA. In contrast, Australia has both national policies and initiatives (see www.copmi.net.au) that foster FFP in mental health settings for children living with parental mental illness. In comparison, the family-related policy initiatives in the USA have contributed to expanding FFP wraparound practices and evaluating systems of care to develop less restrictive forms of care and preserve families with the ultimate aim of reducing health and welfare costs (SAMHSA, 2004). Further, in cultural contexts where individualised health care and recovery is less robust, family participation in family members' recovery may occur more readily as FFP aligns more closely with cultural expectations (Enoka et al., 2013). The ways of thinking about and implementing FFP therefore, can be influenced by cultural considerations, funding priorities, policy settings and guidelines that promote best practice.

In terms of practice implications, the papers illustrated the relevance of FFP throughout the clinical process, from consumer access/identification and engagement, to assessment, support and management, and review. They also illustrate the relevance of service context and the work 


\section{ACCEPTED MANUSCRIPT}

environment in which FFP can occur, as well as the efforts required to tackle ongoing barriers to FFP. The six inter-relating family-focused core practices (Table 3) provide a starting point in defining what approaches and practices could be incorporated in services and delivered by clinicians in partnership with consumers and family members. FFP is everyone's responsibility, regardless of whether it is a child, youth or adult service (Foster et al., 2012). For child and youth mental health clinicians, the defining feature of FFP is the systematic incorporation of parent/carer mental health into a family-focused care plan. Conversely, for adult mental health clinicians, it is an acknowledgement of parenting and child and youth mental health. Importantly, FFP comprises clinicians' willingness, capacity and capability to see the relationship between the primary/referred person and their 'key others'.

\section{CONCLUSIONS}

As a way forward in developing a consistent and effective care for families in mental health, and strengthening family members' wellbeing and improving outcomes, the following key principles and practices synthesised from the literature in this review are recommended as a beginning point for further work in the field. They can be used as a foundation to inform the testing of a conceptual framework for FFP applicable across mental health services.

\section{Principles of FFP}

Four key principles can be understood to shape FFP including;

1) a belief that consumers' (child or adult) families play a pivotal role in their recovery;

2) that consumers and their families can be empowered to address and meet their needs;

3) that it is possible to support consumers via their family;

4) that the relationships between clinician and consumer, clinician and family, and between 


\section{ACCEPTED MANUSCRIPT}

consumer and family members, are key to enabling a 'whole of family' approach.

These principles highlight the crucial importance of clinicians using a process of partnership with consumers and families for better outcomes.

\section{Practices of FFP}

The six core and inter-related practices identified in this review (Table 3) form a useful foundation from which to develop further specificity regarding FFP. However, these findings are generated from a review of past practices in mental health and are not necessarily best practice. Accordingly, the practices identified here do not necessarily mean that other practices may not be relevant.

The findings of the review have several implications for mental health clinical practice, education, policy and research. Key stakeholders (such as clinicians and their employers and professional organisations) are recommended to take cognisance of the principles of FFP when working towards adopting a 'whole of family approach' within mental health services. Mental health services need to be informed by a holistic, family and recovery orientated philosophy. To foster and sustain this type of service delivery, it is essential that mental health services have the necessary resources in place, including workforce education programs, FFP policy, practice guidelines and financial resources. Clinical leadership is also central. This is important, particularly in acute mental health settings, where a biomedical and professional-centred approach typically prevails.

By synthesizing available research into FFP in child and adult settings in this review, we have been able to clarify and operationalise clinicians' practice and highlighted key areas for 


\section{ACCEPTED MANUSCRIPT}

professional development and service evaluation. Such a framework allows for further testing, research, refinement and advancement.

The review identified several gaps in knowledge regarding FFP that would benefit from further investigation. Research on 'age' as a variable in FFP needs further evidence: for example, day hospital treatment for infants, toddlers and preschoolers (Furniss et al., 2013); and 'early' onset diagnoses such as psychosis (Sin et al., 2007) and bipolar disorder (Miklowitz et al., 2006) where families may be encountering mental health clinicians and services for the first time, and when the consumer is a child, youth or transitioning adult. Other areas include family psychoeducational needs in relation to the differences between developmental- and illnessrelated behaviors; the need for integrated ways of measuring outcomes of FFP; and examining what it means to collaborate with families as decision makers. Qualitative approaches to take account of families' stories/perspectives that may be based on different assumptions about what is helpful and which may differ from that of professionals, would strengthen investigation. Further research is required to explore whether particular practice settings and professional disciplines should dictate the range of family-focused activities that occur, especially considering the continuum of family-focused practices that exist and the potential differences in the capacity of different healthcare disciplines to engage in FFP (see Maybery et al., 2014).

The findings of this review also highlight a need for further theory development in FFP, so that a shared understanding can be developed around what clinicians currently do, and should do, when working with families. Such a theory would render FFP tangible and enable clinicians to be consistent in their FFP approach. At the same time, in synthesising and unpacking the terms, principles and practices underlying FFP, this review has contributed to the development of FFP 


\section{ACCEPTED MANUSCRIPT}

theory for clinicians within adult and child and youth mental health services. However, a consolidation of theory development is still required, particularly around models of intervention and an accompanying efficacy base. Developing a robust theoretical construct of FFP has significant implications for effectiveness of professional practice, adoption of FFP by services, workforce education, and service evaluation. 


\section{ACCEPTED MANUSCRIPT}

\section{References}

Allen, R. I., \& Petr, C. G. (1998). Rethinking family-centred practice. American Journal of Orthopsychiatry, 68(1), 4-15.

Anderson, J. A., Wright, E. R., Kooreman, H. E., Mohr, W. K., \& Russell, L. A. (2003). The Dawn Project: A model for responding to the needs of children with emotional and behavioral challenges and their families. Community Mental Health Journal, 39(1), 6374.

Aubry, T., Farrell, S., O'Connor, B. V., Kerr, P., Weston, J., \& Elliott, D. (2000). Family-focused case management: A case study of an innovative demonstration program. Canandian Journal of Community Mental Health, 19(1), 63-78.

Bartlett, R., Herrick, C. A., \& Greninger, L. (2006). Using a system of care framework for the mental health treatment of children and adolescents. The Journal for Nurse Practitioners, 2(9), 593-598.

Beardslee, W. R., Wright, E. J., Gladstone, T. R., \& Forbes, P. (2007). Long-term effects from a randomized trial of two public health preventive interventions for parental depression. Journal of Family Psychology, 21(4), 703-713. 


\section{ACCEPTED MANUSCRIPT}

Centre for Addiction and Mental Health. (2004). Putting family-centered care philosophy into practice. Retrieved 31 ${ }^{\text {st }}$ March 2015 from http://www.camh.ca/en/hospital/Documents/www.camh.net/Care_Treatment/Community _and_social_supports/Social_Support/FCCI/FCC_Better_Practices_PDF.pdf

Cowling, V., \& Garrett, M. (2009). Child and family inclusive practice: A pilot program in a community adult mental health service. Australasian Psychiatry, 17(4), 279-282.

Dausch, B. M., Cohen, A. N., Glynn, S., McCutcheon, S., Perlick, D. A., Rotondi, A., . . Dixon, L. (2012). An intervention framework for family involvement in the care of persons with psychiatric illness: Further guidance from family forum II. American Journal of Psychiatric Rehabilitation, 15(1), 5-25.

Dempsey, I., \& Keen, D. (2008). A review of processes and outcomes in family-centred services for children with a disability. Topics in Early Childhood Special Education, 28, 42-52.

Devlin, J. M., \& O'Brien, L. M. (1999). Children of parents with mental illness. I: An overview from a nursing perspective. Australian \& New Zealand Journal of Mental Health Nursing, 8(1), 19-29. 


\section{ACCEPTED MANUSCRIPT}

Dunst, C., Trivette, C., \& Hamby, D.W. (2007). Meta-analysis of family-centred helpgiving practices research. Mental Retardation and Developmental Disabilities Research Reviews, 13(4), 370-378.

Enoka, M. I. S., Tenari, A., Sili, T., Peteru, L., Tago, P., \& Blignault, I. (2013). Developing a culturally appropriate mental health care service for Samoa. Asia-Pacific Psychiatry, $5(2), 108-111$.

Family Mental Health Alliance (2006). Caring together: Families as partners in the mental health and addiction system. Retrieved $31^{\text {st }}$ March, 2015 from http://ontario.cmha.ca/public_policy/caring-together-families-as-partners-in-the-mentalhealth-and-addiction-system/

Foster, K., O'Brien, L., \& Korhonen, T. (2012). Developing resilient children and families when parents have mental illness: A family-focused approach. International Journal of Mental Health Nursing, 21(1), 3-11.

Furniss, T., Muller, J., Achtergarde, S., Wessing, I., Averbeck-Holocher, M., \& Postert, C. (2013). Implementing psychiatric day treatment for infants, toddlers, preschoolers and their families: A study from a clinical and organizational perspective. International Journal of Mental Health Systems, 7(1), 12. 


\section{ACCEPTED MANUSCRIPT}

Gladstone, B.M., McKeever, P., Seeman, M., \& Boydell, K. M. (2014). Analysis of a support group for children of parents with mental illnesses: managing stressful situations. Qualitative Health Research, 24(9):1171-1182.

Glynn, S.M., Cohen, A.N., Dixon, L.B., \& Niv, J. (2006). The potential impact of the recovery movement on family interventions for schizophrenia: opportunities and obstacles. Schizophrenia Bulletin, 32(3), 451-463.

Gopalan, G., Franco, L. M., Dean-Assael, K., McGuire-Schwartz, M., Chacko, A., \& McKay, M. (2014). Statewide implementation of the 4 Rs and 2 Ss for strengthening families. Journal of Evidence-Based Social Work, 11(1-2), 84-96.

Gross, V., \& Goldin, J. (2008). Dynamics and dilemmas in working with families in Inpatient CAMH services. Clinical Child Psychology \& Psychiatry, 13(3), 449-461.

Handron, D. S., Dosser, D. A., McCammon, S. L., \& Powell, J. Y. (1998). "Wraparound" - The Wave of the future: Theoretical and professional practice implications for children and families with complex needs. Journal of Family Nursing, 4(1), 65-86.

Heitmann, D., Schmuhl, M., Reinisch, A., \& Bauer, U. (2012). Primary prevention for children of mentally ill parents: The Kanu-program. Journal of Public Health (Germany), 20(2), $125-130$. 


\section{ACCEPTED MANUSCRIPT}

Hinden, B. R., Biebel, K., Nicholson, J., \& Mehnert, L. (2005). The Invisible Children's Project: Key ingredients of an intervention for parents with mental illness. Journal of Behavioral Health Services and Research, 32(4), 393-408.

Hoagwood, K.E. (2005). Family-based services in children's mental health: a research review and synthesis. Journal of Child Psychology \& Psychiatry, 46, 690-713.

Houlihan, D., Sharek, D., \& Higgins, A. (2013). Supporting children whose parent has a mental health problem: An assessment of the education, knowledge, confidence and practices of registered psychiatric nurses in Ireland. Journal of Psychiatric \& Mental Health Nursing, 20(4), 287-295.

Hseih, H., \& Shannon, S. (2005). Three approaches to qualittive content analysis. Qualitative Health Research, 15(9), 1277-1288.

Jessop, M. E., \& de Bondt, N. (2012). A consultation service for adult mental health service clients who are parents and their families. Advances in Mental Health, 10(2), 149-156.

Jolley, J., \& Shields, L. (2009). The evolution of family-centred care. Journal of Paediatric Nursing, 24(2), 164-170. 


\section{ACCEPTED MANUSCRIPT}

Kilmer, R. P., Cook, J. R., \& Palamaro Munsell, E. (2010). Moving from principles to practice: Recommended policy changes to promote family-centred care. American Journal of Community Psychology, 46(3-4), 332-341.

Korhonen, T., Pietilä, A. M., \& Vehviläinen-Julkunen, K. (2010a). Are the children of the clients' visible or invisible for nurses in adult psychiatry? A questionnaire survey. Scandinavian Journal of Caring Sciences, 24(1), 65-74.

Korhonen, T., Vehviläinen-Julkunen, K., \& Pietilä, A. (2010b). Do nurses support the patient in his or her role as a parent in adult psychaitry? A survey of mental health nurses in Finland. Archives of Psychiatric Nursing, 24(3), 155-167.

Korhonen, T., Vehviläinen-Julkunen, K., \& Pietilä, A. (2008). Do nurses working in adult psychiatry take into consideration the support network of families affected by parental mental disorder? Journal of Psychiatric \& Mental Health Nursing, 15(9), 767-776.

Lee, M. Y., Greene, G. J., Hsu, K. S., Solovey, A., Grove, D., Fraser, J. S., . . Teater, B. (2009). Utilizing family strengths and resilience: Integrative family and systems treatment with children and adolescents with severe emotional and behavioral problems. Family Process, 48(3), 395-416. 


\section{ACCEPTED MANUSCRIPT}

Lepage, S. J. M. (2005). Family intervention in first episode psychosis. Journal of Family Psychotherapy, 16(3), 85-104.

Lucksted, A, McFarlane, W., Downing, D., Dixon, L., \& Adams, C. (2012). Recent developments in family psychoeducation as an evidence based practice. Journal of Marital and Family Therapy, 38(1), 101-121.

MacFarlane, M. (2011). Family centred care in adult mental health: Developing a collaborative interagency practice. Journal of Family Psychotherapy, 22(1), 56-73.

MacKean, G., Spragins, W., L’Heureux, L., Popp, J., Wilkes, C., \& Lipton, H. (2012). Advancing family-centred care in child and adolescent mental health. A critical review of the literature. Healthcare Quarterly, 15, 64-75.

Maddocks, S., Johnson, S., Wright, N., \& Stickley, T. (2010). A phenomenological exploration of the lived experience of mental health nurses who care for clients with enduring mental health problems who are parents. Journal of Psychiatric \& Mental Health Nursing, 17(8), $674-682$.

Malysiak, R. (1997). Exploring the theory and paradigm base for wraparound. Journal of Child and Family Studies, 6(4), 399-408. 


\section{ACCEPTED MANUSCRIPT}

Maybery, D., Goodyear, M., O'Hanlon, B., Cuff, R., \& Reupert, A. (2014). Profession differences in family focused practice in the adult mental health system. Family Process, 19(10), 1-10.

Maybery, D., Goodyear, M., \& Reupert, A. (2012). The family-focused mental health practice questionnaire. Archives of Psychiatric Nursing, 26(2), 135-144.

Maybery, D., \& Reupert, A. (2006). Workforce capacity to respond to children whose parents have a mental illness. Australian and New Zealand Journal of Psychiatry, 40(8), 657664.

Mikkelsen, G., \& Frederiksen, K. (2011). Family-centred care of children in hospital - a concept analysis Journal of Advanced Nursing 67(5), 1152-1162.

Miklowitz, D. J., Biuckians, A., \& Richards, J. A. (2006). Early-onset bipolar disorder: A family treatment perspective. Development and Psychopathology, 18(4), 1247-1265.

Modlin, H. (2004). The Development of a Parent Support Group as a Means of Initiating Family Involvement in a Residential Program, Child \& Youth Services, 25,1(2), 169-189.

Mosier, J., Burlingame, G. M., Wells, M. G., Ferre, R., Latkowski, M., Johansen, J., . . Walton, E. (2001). In-home, family-centred psychiatric treatment for high-risk children and youth. Children's Services: Social Policy, Research, \& Practice, 4(2), 51-68. 


\section{ACCEPTED MANUSCRIPT}

Mottaghipour, Y., \& Bickerton, A. (2005). The pyramid of family care: A framework for family involvement with adult mental health services. Australian e-Journal for the Advancement of Mental Health, 4(3), 210-217.

Mullen, A., Murray, L., \& Happell, B. (2002). Multiple family group interventions in first episode psychosis: Enhancing knowledge and understanding. International Journal of Mental Health Nursing, 11(4), 225-232.

National Institute for Health and Clinical Excellence (2009) Schizophrenia: Core interventions in the treatment and management of schizophrenia in primary and secondary care (update). London: National Institute for Health and Clinical Excellence. Available from: www.nice.org.uk

Nicholson, J. (2007). Helping parents with mental illness. Behavioral Healthcare, 27(5), 32-33.

Nicholson, J., Reupert, A., Grant, A., Lees, R., Maybery, D., Murdoch, E., ... Diggins, M. (2015). The policy context and change for families living with parental mental illness. In A. Reupert, D. Maybery, J. Nicholson, M. Göpfert \& M. Seeman (Eds.). Parental psychiatric disorder: Distressed parents and their families (pp.354-364). London: Cambridge University Press. 


\section{ACCEPTED MANUSCRIPT}

O'Brien, L., Brady, P., Anand, M., \& Gillies, D. (2011). Children of parents with a mental illness visiting psychiatric facilities: Perceptions of staff. International Journal of Mental Health Nursing, 20(5), 358-363.

Osher, T.W., \& Osher, D.M. (2002). The paradigm shift to true collaboration with families. Journal of Child \& Family Studies, 11, 47-60.

Patton, M.Q. (2002). Qualitative research \& evaluation methods ( $3^{\text {rd }}$ ed). Sage: Thousand Oaks.

Pierpont, J. H., \& McGinty, K. (2004). Using family-oriented treatment to improve placement outcomes for children and youth in residential treatment. Journal of Human Behavior in the Social Environment, 9(1-2), 147-163. doi: 10.1300/J137v09n01_10

Pitschel-Walz, G., Leucht, S., Bauml, J., Kissling, W., \& Engel, R.R. (2001). The effect of family interventions on relapse and rehospitalization in schizophrenia: a meta-analysis. Schizophrenia Bulletin, 27(1), 73-92.

Reupert, A., \& Maybery, D. (2014). Practitioners' experiences of working with families with complex needs. Journal of Psychiatric and Mental Health Nursing, 21(7), 642-651. 


\section{ACCEPTED MANUSCRIPT}

Reupert, A., Maybery, D. \& Kowalenko, N. (2012). Children whose parents have a mental illness: prevalence, need and treatment. Medical Journal of Australia, 16, 7-9.

Substance Centre for Mental Health Services, Substance Abuse and Mental Health Services Administration (SAMHSA) (2004). The Comprehensive Community Mental Health Services for Children and Their Families Program, Evaluation findings-Annual report to Congress, 2004. Accessed at http://store.samhsa.gov/shin/content//SMA-CBE2004/SMA-CB-E2004.pdf

Schmidt, L., \& Monaghan, J. (2012). Intensive family support services: A consultative model of education and support. American Journal of Psychiatric Rehabilitation, 15(1), 26-43.

Sin, J., Moone, N., \& Newell, J. (2007). Developing services for the carers of young adults with early-onset psychosis - implementing evidence-based practice on psycho-educational family intervention. Journal of Psychiatric and Mental Health Nursing, 14(3), 282-290.

Whittemore, R. \& Knafl, K. (2005). The integrative review: updated methodology. Journal of Advanced Nursing, 52(5), 546-553.

Woolston, J. (2007). 2007 Helping youths with severe emotional disturbances at risk of institutionalization. Psychiatric Services, 58(10), 1369-1371.

Young, M. E., \& Fristad, M. A. (2007). Evidence based treatments for bipolar disorder in children and adolescents. Journal of Contemporary Psychotherapy, 37(3), 157-164. 


\section{ACCEPTED MANUSCRIPT}

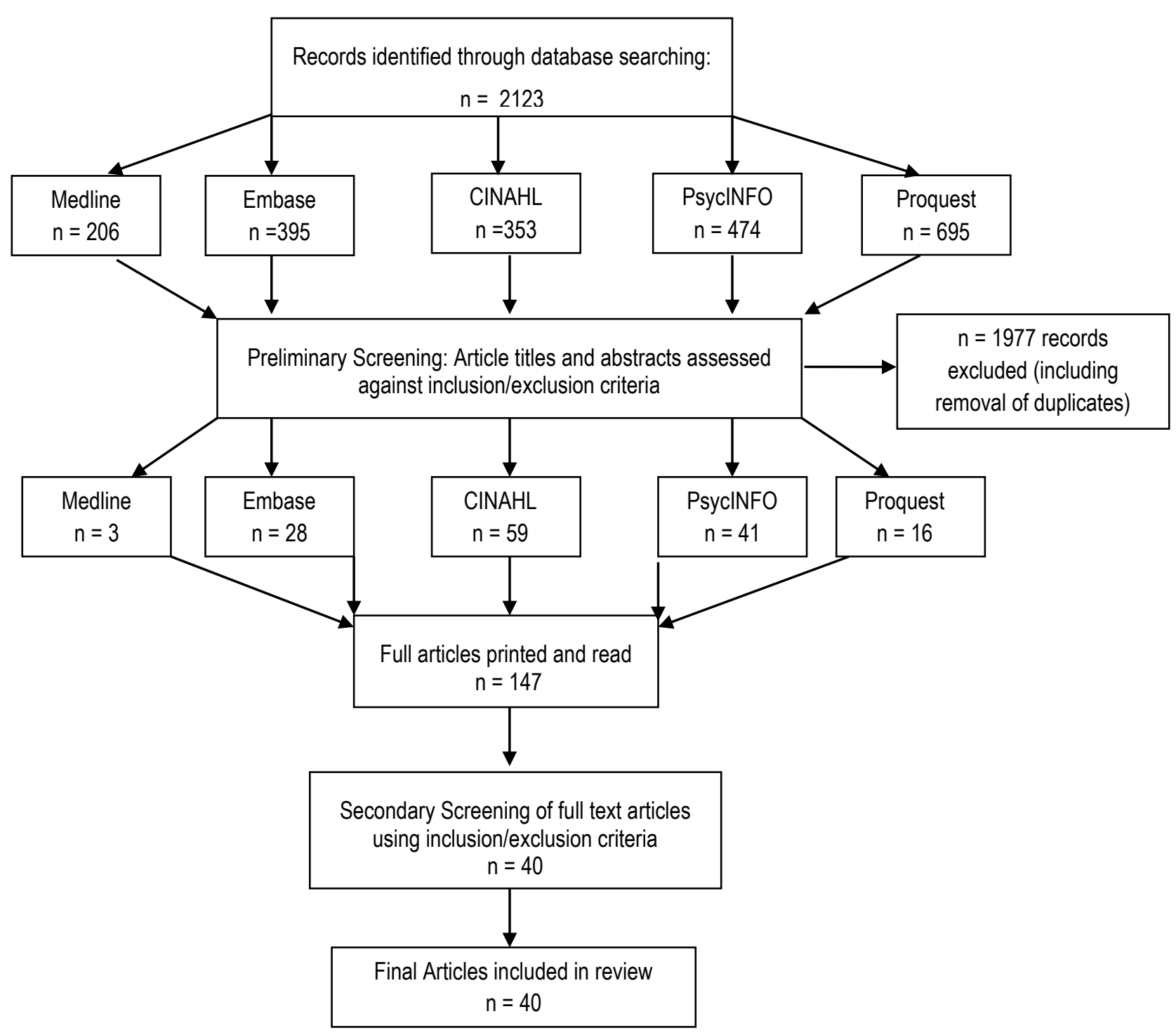

Figure 1: Search and Screening 


\section{ACCEPTED MANUSCRIPT}

Table 1: Search terms

\begin{tabular}{|c|c|c|}
\hline Content Area & Subject Headings & Search Terms \\
\hline $\begin{array}{l}\text { 1. Construct: Family } \\
\text { Focused Practice }\end{array}$ & $\begin{array}{l}\text { Family Focused } \\
\text { Family Centred }\end{array}$ & $\begin{array}{l}\text { "family focused" } \\
\text { OR "family centred" } \\
\text { OR "family centred" } \\
\text { OR “family sensitive" } \\
\text { OR “family oriented" } \\
\text { OR “family guided" } \\
\text { OR “family friendly" } \\
\text { OR "family inclusive" } \\
\text { OR "family driven" }\end{array}$ \\
\hline \multicolumn{3}{|l|}{ AND } \\
\hline $\begin{array}{l}\text { 2. Context: Professional } \\
\text { practice }\end{array}$ & $\begin{array}{l}\text { intervention } \\
\text { practitioner } \\
\text { professional } \\
\text { workforce } \\
\text { community mental health }\end{array}$ & $\begin{array}{l}\text { care or practice* } \\
\text { OR practitioner } \\
\text { OR intervention } \\
\text { OR therapy } \\
\text { OR treatment } \\
\text { OR workforce } \\
\text { OR profession* } \\
\text { OR "community mental }\end{array}$ \\
\hline
\end{tabular}




\section{ACCEPTED MANUSCRIPT}

\begin{tabular}{|l|l|l|}
\hline \multicolumn{2}{|l|}{} & \multicolumn{2}{|l|}{ health" } \\
\hline AND & Mental health & "mental health" \\
& Mental disorders & OR "mental disorder" \\
& Mentally ill & OR "mental disorders" \\
& Child of impaired parents & OR "mental illness" \\
& OR "child of impaired \\
& & parents" \\
& & OR "parental mental illness" \\
& & OR "mentally ill" \\
\end{tabular}

Limit to English language and years 1994-2014. 


\section{ACCEPTED MANUSCRIPT}

Table 2: Included papers \& family-focused practice conceptualisation

\begin{tabular}{|c|c|c|c|c|}
\hline $\begin{array}{l}\text { Author, } \\
\text { Country \& } \\
\text { Type of paper }\end{array}$ & $\begin{array}{l}\text { Service } \\
\text { orientation }\end{array}$ & Family type & $\begin{array}{l}\text { FFP } \\
\text { Description/Terminolo } \\
\text { gy }\end{array}$ & $\begin{array}{l}\text { Principles of } \\
\text { FFP }\end{array}$ \\
\hline $\begin{array}{l}\text { Allen \& Petr, } \\
\text { (1998); } \\
\text { USA } \\
\text { Theoretical and } \\
\text { historical } \\
\text { review of FFP }\end{array}$ & Children & $\begin{array}{l}\text { Family of } \\
\text { origin: } \\
\text { children with } \\
\text { mental } \\
\text { health issues } \\
\text { and their } \\
\text { families }\end{array}$ & $\begin{array}{l}\text { Family -centred service } \\
\text { delivery (FCSD): } \\
\text { program }\end{array}$ & $\begin{array}{l}\text { Extend current } \\
\text { model of FCSD } \\
\text { to include: family } \\
\text { as unit of } \\
\text { attention; } \\
\text { informed family } \\
\text { choice; family } \\
\text { strengths } \\
\text { perspective }\end{array}$ \\
\hline $\begin{array}{l}\text { Preliminary } \\
\text { evaluation of a } \\
\text { ‘systems of } \\
\text { care' project. }\end{array}$ & $\begin{array}{l}\text { Child/ youth: } \\
\text { 5-17 years } \\
\text { services }\end{array}$ & $\begin{array}{l}\text { Family of } \\
\text { origin: } \\
\text { parents and } \\
\text { their children } \\
\text { with mental } \\
\text { health issues }\end{array}$ & $\begin{array}{l}\text { Systems of care as a } \\
\text { different \& non- } \\
\text { traditional form of } \\
\text { service provision : } \\
\text { program }\end{array}$ & $\begin{array}{l}\text { Family centred \& } \\
\text { culturally } \\
\text { competent; } \\
\text { involves funding } \\
\text { streams of } \\
\text { multiple payers } \\
\text { [e.g. education, } \\
\text { child welfare, }\end{array}$ \\
\hline
\end{tabular}




\section{ACCEPTED MANUSCRIPT}

\begin{tabular}{|c|c|c|c|c|}
\hline & & & & $\begin{array}{l}\text { mental health]; } \\
\text { providers strive } \\
\text { to support \& } \\
\text { strengthen } \\
\text { natural supports } \\
\text { for families }\end{array}$ \\
\hline $\begin{array}{l}\text { Aubry et al. } \\
\text { (2001); Canada } \\
\text { Discussion of } \\
\text { program and } \\
\text { preliminary } \\
\text { evaluation } \\
\text { using program } \\
\text { logic model }\end{array}$ & Adult & $\begin{array}{l}\text { Family of } \\
\text { origin: } \\
\text { Consumers } \\
\text { and their } \\
\text { parents }\end{array}$ & $\begin{array}{l}\text { Family focused case } \\
\text { management } \\
\text { program }\end{array}$ & $\begin{array}{l}\text { Partnership with } \\
\text { service users and } \\
\text { their families; } \\
\text { program } \\
\text { developed in } \\
\text { collaboration } \\
\text { with service users } \\
\text { and their } \\
\text { families. } \\
\text { Autonomy of } \\
\text { service user and } \\
\text { their families - } \\
\text { the family } \\
\text { decides if family } \\
\text { managed case }\end{array}$ \\
\hline
\end{tabular}




\section{ACCEPTED MANUSCRIPT}

\begin{tabular}{|c|c|c|c|c|}
\hline & & & & $\begin{array}{l}\text { relevant and } \\
\text { required. }\end{array}$ \\
\hline $\begin{array}{l}\text { Bartlett et al. } \\
\text { (2006); } \\
\text { USA } \\
\text { Discussion. } \\
\text { Presents key } \\
\text { principles of } \\
\text { 'systems of } \\
\text { care' \& how } \\
\text { model works }\end{array}$ & Child/youth & $\begin{array}{l}\text { Family of } \\
\text { origin: } \\
\text { parents and } \\
\text { their children } \\
\text { with mental } \\
\text { health issues }\end{array}$ & Systems of care model & $\begin{array}{l}\text { Child \& family } \\
\text { centre of care } \\
\text { Goal to make } \\
\text { parent part of } \\
\text { child's treatment } \\
\text { team with equal } \\
\text { status to } \\
\text { professional } \\
\text { provider; as } \\
\text { experts on their } \\
\text { own child. } \\
\text { farent partners } \\
\text { 'natural' supports } \\
\text { registered nurse } \\
\text { with advanced } \\
\text { practice }\end{array}$ \\
\hline
\end{tabular}




\section{ACCEPTED MANUSCRIPT}

\begin{tabular}{|c|c|c|c|c|}
\hline & & & & $\begin{array}{l}\text { including family } \\
\text { \& community } \\
\text { resources } \\
\text { Children are } \\
\text { involved } \\
\text { 'wherever } \\
\text { possible' } \\
\text { Holistic, } \\
\text { culturally } \\
\text { competent, child- } \\
\text { and family- } \\
\text { centred and } \\
\text { care in least } \\
\text { community based } \\
\text { care; } \\
\text { services; } \\
\text { individualized setting }\end{array}$ \\
\hline $\begin{array}{l}\text { Beardslee et al., } \\
\text { (2007); USA }\end{array}$ & $\begin{array}{l}\text { Child/youth } \\
\text { (adolescent) }\end{array}$ & $\begin{array}{l}\text { Family of } \\
\text { procreation: }\end{array}$ & $\begin{array}{l}\text { Family- centred } \\
\text { preventive interventions }\end{array}$ & $\begin{array}{l}\text { Family } \\
\text { psychoeducation }\end{array}$ \\
\hline
\end{tabular}




\section{ACCEPTED MANUSCRIPT}

\begin{tabular}{|c|c|c|c|c|}
\hline $\begin{array}{l}\text { Quantitative } \\
\text { evaluation of } \\
\text { two public } \\
\text { health } \\
\text { interventions for } \\
\text { parental } \\
\text { depression }\end{array}$ & & $\begin{array}{l}\text { consumers } \\
\text { and their } \\
\text { children }\end{array}$ & for parental depression & $\begin{array}{l}\text { intervention } \\
\text { goals to promote } \\
\text { long term family } \\
\text { functioning }\end{array}$ \\
\hline $\begin{array}{l}\text { Cowling \& } \\
\text { Garrett (2009); } \\
\text { Australia } \\
\text { Discussion. } \\
\text { Program } \\
\text { description. }\end{array}$ & Adult & $\begin{array}{l}\text { Family of } \\
\text { procreation: } \\
\text { consumers } \\
\text { and their } \\
\text { dependent } \\
\text { children }\end{array}$ & $\begin{array}{l}\text { Child and family } \\
\text { inclusive practice }\end{array}$ & $\begin{array}{l}\text { Strengthen and } \\
\text { build on parents } \\
\text { and children's' } \\
\text { capacity to } \\
\text { manage and to } \\
\text { make sense of } \\
\text { their experience; } \\
\text { Family centred } \\
\text { and child } \\
\text { inclusive practice } \\
\text { is possible within } \\
\text { community } \\
\text { mental health } \\
\text { services; }\end{array}$ \\
\hline
\end{tabular}




\section{ACCEPTED MANUSCRIPT}

\begin{tabular}{|c|c|c|c|c|}
\hline & & & & $\begin{array}{l}\text { Support provided } \\
\text { via child and } \\
\text { family inclusive } \\
\text { practice program; }\end{array}$ \\
\hline $\begin{array}{l}\text { Dausch et } \\
\text { al.,(2012); USA } \\
\text { Family forums } \\
\text { held with } \\
\text { researchers, } \\
\text { administrators } \\
\text { and clinicians. } \\
\text { Discussion of an } \\
\text { intervention } \\
\text { framework }\end{array}$ & Adult & $\begin{array}{l}\text { Family of } \\
\text { origin: } \\
\text { Family } \\
\text { defined as } \\
\text { relatives, } \\
\text { supportive } \\
\text { family } \\
\text { members of } \\
\text { the consumer }\end{array}$ & $\begin{array}{l}\text { Family involvement and } \\
\text { services : intervention } \\
\text { framework }\end{array}$ & $\begin{array}{l}\text { Family } \\
\text { involvement is } \\
\text { important for } \\
\text { recovery and } \\
\text { holistic care } \\
\text { Need to provide a } \\
\text { variety of } \\
\text { services and } \\
\text { family choice } \\
\text { Empowerment of } \\
\text { service user and } \\
\text { family to make } \\
\text { family should be } \\
\text { choices } \\
\text { Consumers and } \\
\text { in service choices }\end{array}$ \\
\hline
\end{tabular}




\section{ACCEPTED MANUSCRIPT}

\begin{tabular}{|c|c|c|c|c|}
\hline & & & & $\begin{array}{l}\text { with consumers } \\
\text { and family } \\
\text { important to } \\
\text { identify and to } \\
\text { address needs } \\
\text { Consumer } \\
\text { centred and } \\
\text { strengths based }\end{array}$ \\
\hline $\begin{array}{l}\text { Devlin \& O' } \\
\text { Brien (1999); } \\
\text { Australia } \\
\text { Discussion of a } \\
\text { mental health } \\
\text { model for } \\
\text { mental health } \\
\text { nursing } \\
\text { advocacy }\end{array}$ & Adult & $\begin{array}{l}\text { Family of } \\
\text { procreation: } \\
\text { adult } \\
\text { consumers } \\
\text { and their } \\
\text { dependent } \\
\text { children }\end{array}$ & $\begin{array}{l}\text { Model for mental health } \\
\text { nursing advocacy }\end{array}$ & $\begin{array}{l}\text { Advocacy \& } \\
\text { collaboration } \\
\text { Prevention \& } \\
\text { health promotion } \\
\text { Holistic model of } \\
\text { service provision } \\
\text { Family pivotal as } \\
\text { the primary } \\
\text { environment of } \\
\text { the adult } \\
\text { consumer }\end{array}$ \\
\hline $\begin{array}{l}\text { Enoka et al. } \\
\text { (2013); Samoa }\end{array}$ & Adult & $\begin{array}{l}\text { Family of } \\
\text { origin: }\end{array}$ & $\begin{array}{l}\text { Mental health care } \\
\text { services: a family }\end{array}$ & $\begin{array}{l}\text { Family as active } \\
\text { partner in care }\end{array}$ \\
\hline
\end{tabular}




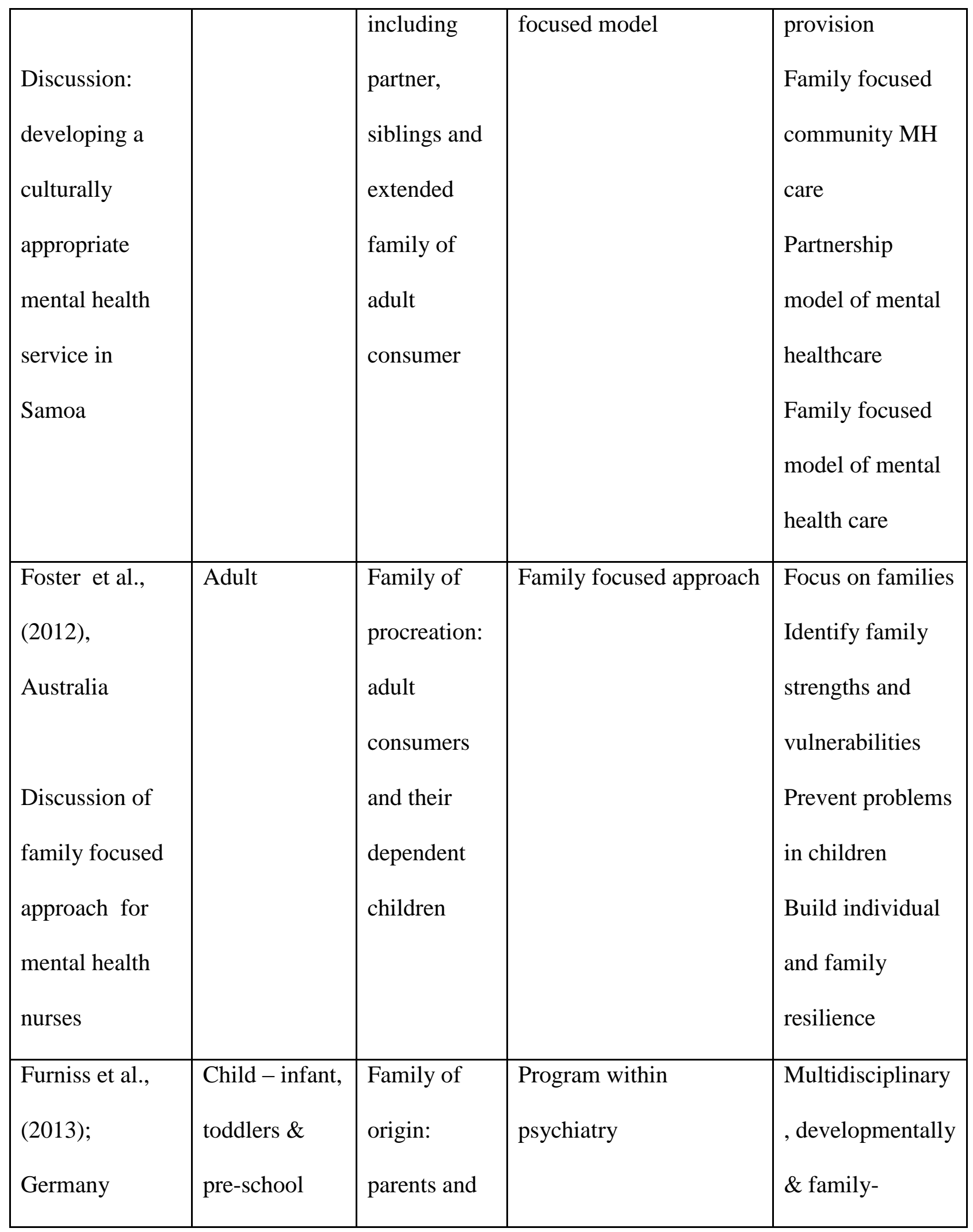




\section{ACCEPTED MANUSCRIPT}

\begin{tabular}{|c|c|c|c|}
\hline \multirow{3}{*}{$\begin{array}{l}\text { Discusses a } \\
\text { psychiatric day }\end{array}$} & \multirow{2}{*}{$\begin{array}{l}\text { children \& } \\
\text { parents/sibling }\end{array}$} & \multirow{2}{*}{$\begin{array}{l}\text { their children } \\
\text { with non- }\end{array}$} & \multirow{2}{*}{$\begin{array}{l}\text { oriented } \\
\text { approach }\end{array}$} \\
\hline & & & \\
\hline & $\mathrm{s}$ & transient & Refers to 'family \\
\hline treatment & & mental & psychiatry' as \\
\hline program for & & illness & involving parents \\
\hline infants, toddlers & & & in treatment of \\
\hline and pre- & & & psychiatrically ill \\
\hline schoolers and & & & children; \\
\hline their parents & & & presumes \\
\hline & & & psychopathology \\
\hline & & & of one family \\
\hline & & & member affects \\
\hline & & & mental health of \\
\hline & & & others; thus \\
\hline & & & family member \\
\hline & & & included as \\
\hline & & & imnortant \\
\hline & & & 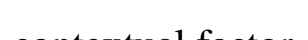 \\
\hline & & & \\
\hline & & & for treatment of \\
\hline & & & index patient; \\
\hline & & & other caregivers \\
\hline & & & can participate \\
\hline
\end{tabular}




\section{ACCEPTED MANUSCRIPT}

\begin{tabular}{|c|c|c|c|c|}
\hline & & & & $\begin{array}{l}\text { where required; } \\
\text { pre-school } \\
\text { siblings of index }\end{array}$ \\
\hline $\begin{array}{l}\text { Gopolan et al. } \\
\text { (2014); USA } \\
\text { Implementation } \\
\text { study of } \\
\text { program for } \\
\text { children with } \\
\text { oppositional } \\
\text { defiant disorder } \\
\text { or conduct } \\
\text { disorder. }\end{array}$ & $\begin{array}{l}\text { Child/youth 7- } \\
11 \mathrm{yrs} \text {. }\end{array}$ & $\begin{array}{l}\text { Family of } \\
\text { origin: } \\
\text { parents and } \\
\text { their children } \\
\text { with } \\
\text { behavior } \\
\text { disorders }\end{array}$ & $\begin{array}{l}4 \text { R's and 2Ss for the } \\
\text { Strengthening Families } \\
\text { Program treatment } \\
\text { program; }\end{array}$ & $\begin{array}{l}\text { Core treatment } \\
\text { components } \\
\text { based on } \\
\text { empirically } \\
\text { supported family- } \\
\text { level influences } \\
\text { on disruptive } \\
\text { behavior } \\
\text { disorders } \\
\text { incorporating } \\
\text { treatment } \\
\text { strategies from } \\
\text { behavioral parent } \\
\text { training and } \\
\text { family therapy } \\
\text { evaluation } \\
\text { Working with } \\
\text { eamilies }\end{array}$ \\
\hline
\end{tabular}




\section{ACCEPTED MANUSCRIPT}

\begin{tabular}{|c|c|c|c|c|}
\hline & & & & $\begin{array}{l}\text { effective because } \\
\text { all members part } \\
\text { of the process } \\
\text { Developed in } \\
\text { collaboration } \\
\text { with families of } \\
\text { youth with } \\
\text { disruptive } \\
\text { behavior } \\
\text { disorders and } \\
\text { mental health } \\
\text { providers }\end{array}$ \\
\hline $\begin{array}{l}\text { Gross \& Goldin, } \\
\text { (2008); UK } \\
\text { Discusses } \\
\text { principles in } \\
\text { practice for } \\
\text { working with } \\
\text { children and }\end{array}$ & Child/youth & $\begin{array}{l}\text { Family of } \\
\text { origin: } \\
\text { parents and } \\
\text { their children } \\
\text { with mental } \\
\text { health tissues }\end{array}$ & $\begin{array}{l}\text { Services embedded in an } \\
\text { Inpatient Child \& } \\
\text { Adolescent Mental } \\
\text { Health facility }\end{array}$ & $\begin{array}{l}\text { Partnership with } \\
\text { parents features } \\
\text { include: mutual } \\
\text { respect; rights to } \\
\text { information; } \\
\text { accountability; } \\
\text { competence and } \\
\text { value accorded to } \\
\text { each individual's }\end{array}$ \\
\hline
\end{tabular}




\section{ACCEPTED MANUSCRIPT}

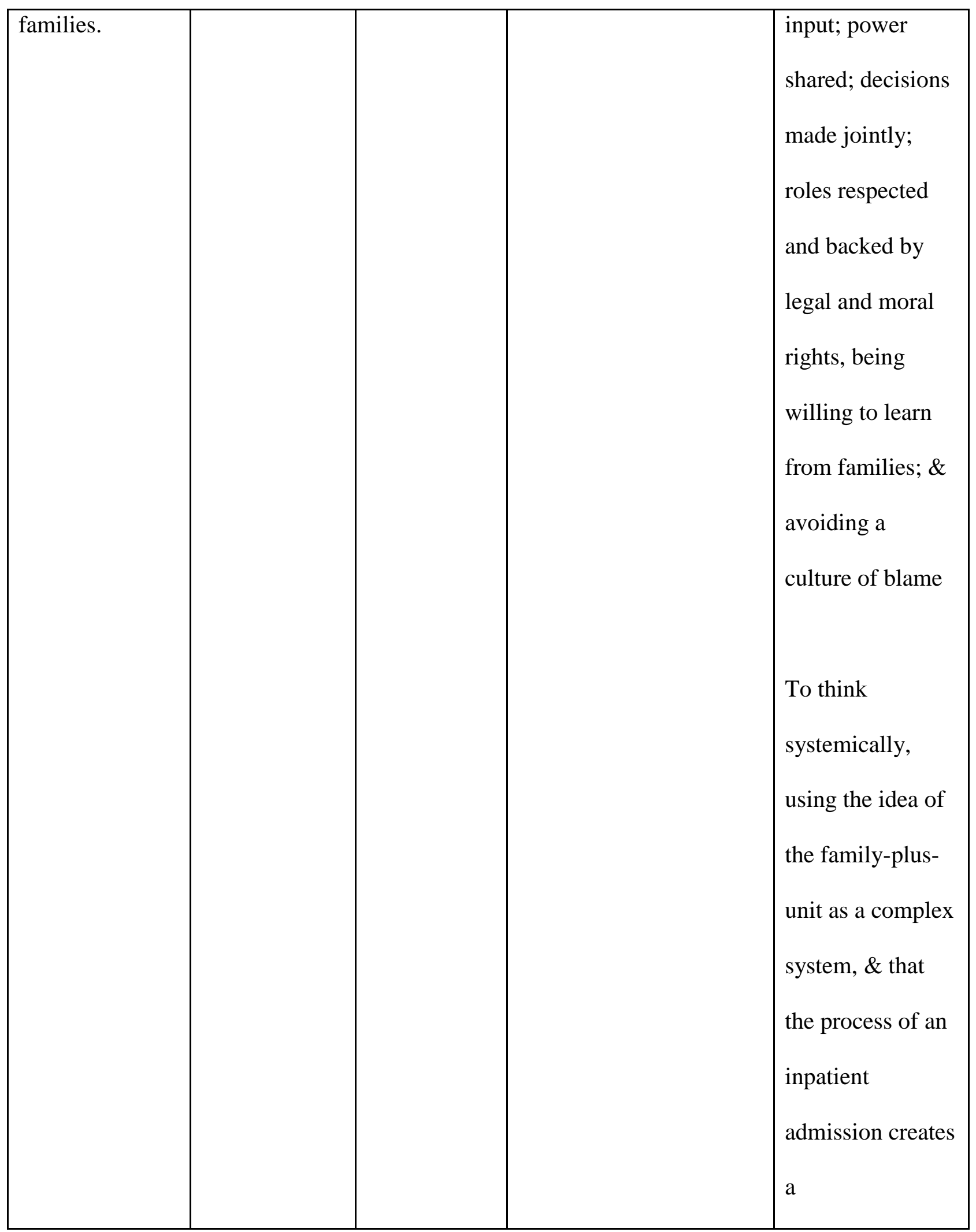




\section{ACCEPTED MANUSCRIPT}

\begin{tabular}{|c|c|c|c|c|}
\hline & & & & $\begin{array}{l}\text { new set of } \\
\text { interconnected } \\
\text { relationships for } \\
\text { child, family, and } \\
\text { staff group } \\
\text { interwoven } \\
\text { together }\end{array}$ \\
\hline $\begin{array}{l}\text { Handron et al., } \\
\text { (1998) } \\
\text { USA } \\
\text { Historical } \\
\text { overview of } \\
\text { wraparound } \\
\text { services \& } \\
\text { political, } \\
\text { economic, } \\
\text { practice } \\
\text { implications and } \\
\text { discursiotical } \\
\text { dion }\end{array}$ & Child/youth & $\begin{array}{l}\text { Family of } \\
\text { origin: } \\
\text { parents and } \\
\text { their children } \\
\text { with mental } \\
\text { health tissues }\end{array}$ & $\begin{array}{l}\text { Wraparound process } \\
\text { model }\end{array}$ & $\begin{array}{l}\text { Strengths based, } \\
\text { family } \\
\text { orientation that } \\
\text { focuses on } \\
\text { uniqueness of } \\
\text { each child and } \\
\text { family; } \\
\text { individualized } \\
\text { and flexible } \\
\text { services used to } \\
\text { define: } 1 . \text { A } \\
\text { philosophy of } \\
\text { service provision; } \\
\text { 2. A unique } \\
\text { mechanism to }\end{array}$ \\
\hline
\end{tabular}




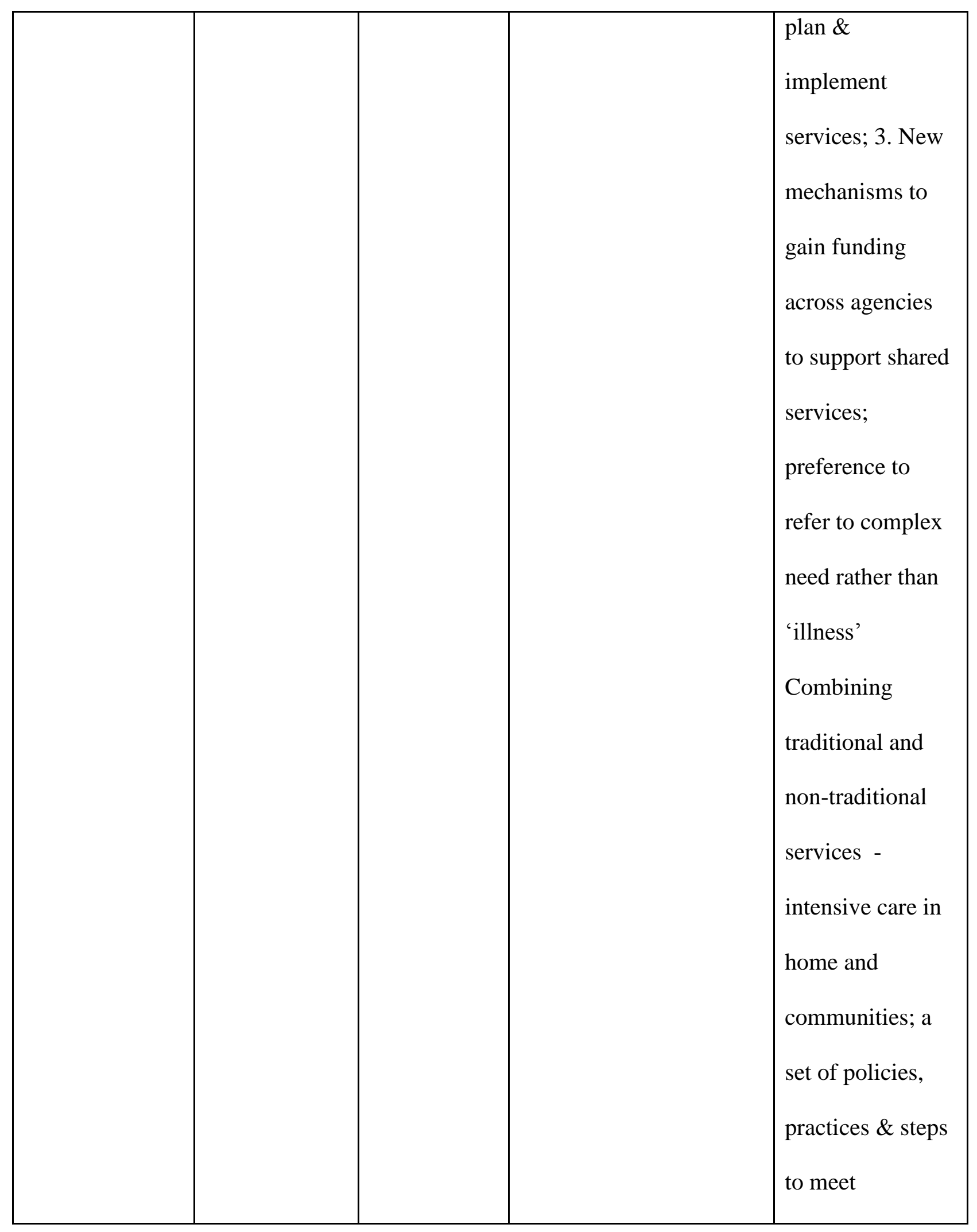




\begin{tabular}{|c|c|c|c|c|}
\hline & & & & $\begin{array}{l}\text { individualized } \\
\text { concerns of child } \\
\text { and family with } \\
\text { complex needs; } \\
\text { Child and family } \\
\text { are expert on } \\
\text { their lives/needs; } \\
\text { vs. services } \\
\text { designed by } \\
\text { professional } \\
\text { assumption; } \\
\text { Wraparound } \\
\text { service provision } \\
\text { described as a } \\
\text { philosophy of a }\end{array}$ \\
\hline $\begin{array}{l}\text { Heitmann et al., } \\
\text { (2012); } \\
\text { Germany } \\
\text { Discussion of }\end{array}$ & Adult & $\begin{array}{l}\text { Family of } \\
\text { procreation: } \\
\text { consumers } \\
\text { and their } \\
\text { dependent }\end{array}$ & Family-centred care & $\begin{array}{l}\text { Discusses family- } \\
\text { centred } \\
\text { philosophies [ie. } \\
\text { Systems of Care } \\
\text { and practice }\end{array}$ \\
\hline
\end{tabular}




\section{ACCEPTED MANUSCRIPT}

\begin{tabular}{|c|c|c|c|c|}
\hline $\begin{array}{l}\text { program } \\
\text { development }\end{array}$ & & children & & $\begin{array}{l}\text { models [i.e. } \\
\text { wraparound] - } \\
\text { idea is to support } \\
\text { family to help } \\
\text { child make gains; } \\
\text { Family system is } \\
\text { important for } \\
\text { helping child } \\
\text { with disorder }\end{array}$ \\
\hline $\begin{array}{l}\text { Hinden et al., } \\
\text { (2005); } \\
\text { USA } \\
\text { Case study } \\
\text { design within a } \\
\text { qualitative } \\
\text { framework; data } \\
\text { obtained from } \\
\text { interviews with } \\
\text { parents, service } \\
\text { providers, and } \\
\text { from family file }\end{array}$ & Adult & $\begin{array}{l}\text { Family of } \\
\text { procreation: } \\
\text { consumers } \\
\text { and their } \\
\text { dependent } \\
\text { children }\end{array}$ & Family centred program & $\begin{array}{l}\text { Focus on } \\
\text { strengths and } \\
\text { trust between } \\
\text { provider and } \\
\text { family; } \\
\text { Focus on } \\
\text { effective } \\
\text { communication, } \\
\text { collaboration and } \\
\text { partnership } \\
\text { between parent } \\
\text { and provider } \\
\text { Strengths based }\end{array}$ \\
\hline
\end{tabular}




\begin{tabular}{|c|c|c|c|c|}
\hline records & & & & approach \\
\hline $\begin{array}{l}\text { Houlihan et al., } \\
\text { (2013); Ireland } \\
\text { Quantitative } \\
\text { surrey with } \\
\text { mental health } \\
\text { nurses }\end{array}$ & Adult & $\begin{array}{l}\text { Family of } \\
\text { procreation: } \\
\text { consumer } \\
\text { and their } \\
\text { dependent } \\
\text { children }\end{array}$ & Family focused care & $\begin{array}{l}\text { Nurses and } \\
\text { services need to } \\
\text { be both child and } \\
\text { family focused. }\end{array}$ \\
\hline $\begin{array}{l}\text { Jessop \& de } \\
\text { Bondt (2012); } \\
\text { Australia } \\
\text { Discussion of a } \\
\text { consultation } \\
\text { service by } \\
\text { child/youth staff } \\
\text { to adult mental } \\
\text { health services }\end{array}$ & Adult & $\begin{array}{l}\text { Family of } \\
\text { procreation: } \\
\text { consumer } \\
\text { and their } \\
\text { dependent } \\
\text { children }\end{array}$ & $\begin{array}{l}\text { Family centred } \\
\text { Family sensitive }\end{array}$ & $\begin{array}{l}\text { Collaboration } \\
\text { between services } \\
\text { critical } \\
\text { Strengths based } \\
\text { approach }\end{array}$ \\
\hline $\begin{array}{l}\text { Kilmer et al. } \\
\text { (2010); USA }\end{array}$ & Child/youth & $\begin{array}{l}\text { Family of } \\
\text { origin: } \\
\text { families of }\end{array}$ & $\begin{array}{l}\text { Family- focused, family- } \\
\text { centred care }\end{array}$ & $\begin{array}{l}\text { System of Care } \\
\text { philosophy with } \\
\text { wraparound as }\end{array}$ \\
\hline
\end{tabular}




\section{ACCEPTED MANUSCRIPT}

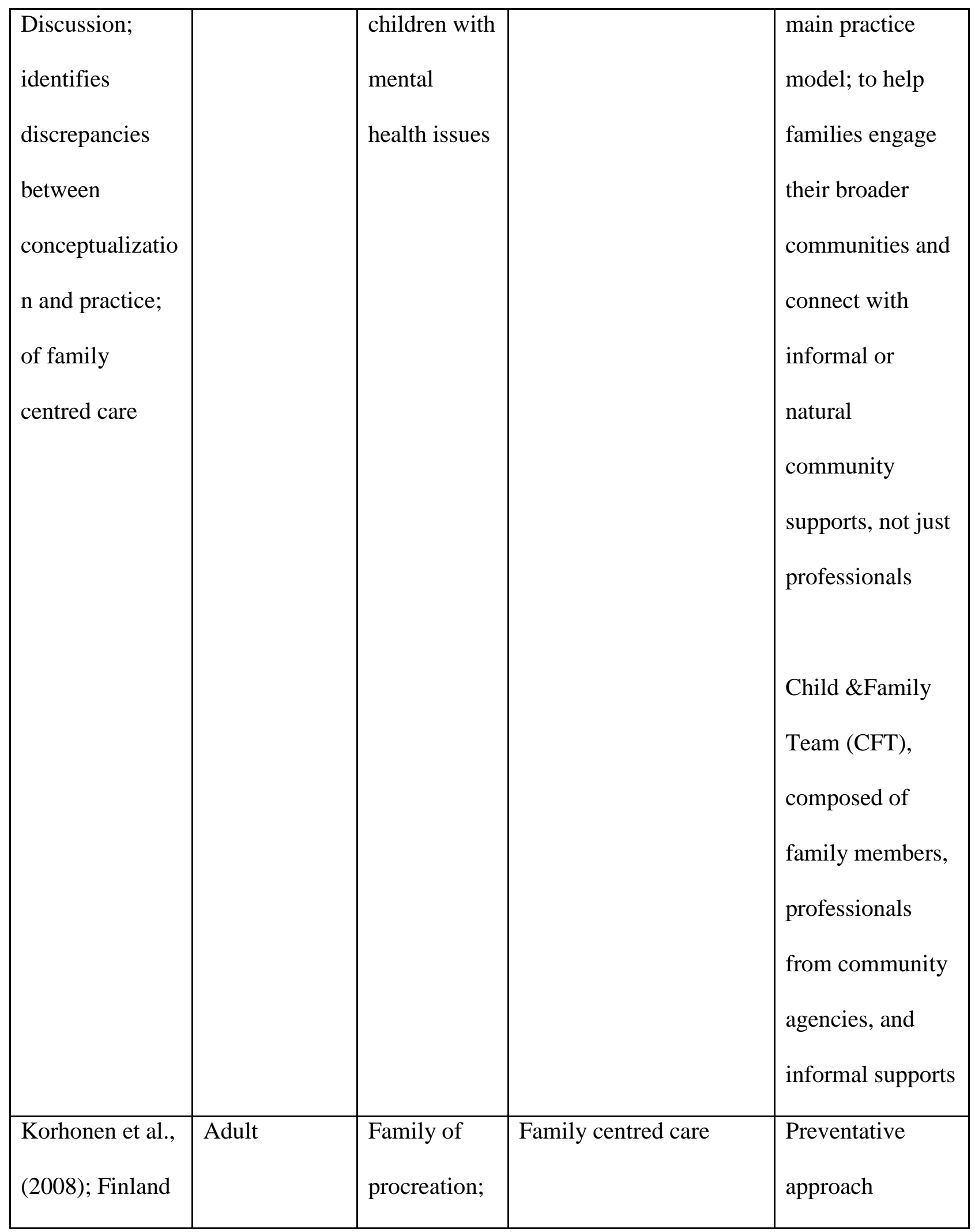




\section{ACCEPTED MANUSCRIPT}

\begin{tabular}{|c|c|c|c|c|}
\hline $\begin{array}{l}\text { Quantitative } \\
\text { survey of } \\
\text { psychiatric } \\
\text { nurses }\end{array}$ & & $\begin{array}{l}\text { consumers } \\
\text { and their } \\
\text { dependent } \\
\text { children }\end{array}$ & & Collaboration \\
\hline $\begin{array}{l}\text { Korhonen et al., } \\
\text { (2010a); } \\
\text { Finland } \\
\text { Quantitative } \\
\text { survey with } \\
\text { psychiatric } \\
\text { nurses }\end{array}$ & Adult & $\begin{array}{l}\text { Family of } \\
\text { procreation: } \\
\text { adult } \\
\text { consumers } \\
\text { and their } \\
\text { children }\end{array}$ & $\begin{array}{l}\text { Family centred care; } \\
\text { Family orientated } \\
\text { approach; } \\
\text { Family orientated care } \\
\text { methods }\end{array}$ & $\begin{array}{l}\text { Prevention } \\
\text { approach } \\
\text { Collaboration } \\
\text { Identifying } \\
\text { parenting status } \\
\text { and supporting } \\
\text { parents to } \\
\text { develop } \\
\text { parenting skills } \\
\text { can promote } \\
\text { recovery } \\
\text { FFP is a multi- } \\
\text { professional issue }\end{array}$ \\
\hline $\begin{array}{l}\text { Korhonen } \\
\text { (2010b) ; }\end{array}$ & Adult & $\begin{array}{l}\text { Family of } \\
\text { procreation: }\end{array}$ & $\begin{array}{l}\text { Family centred care; } \\
\text { Family orientated care }\end{array}$ & $\begin{array}{l}\text { Family orientated } \\
\text { care methods }\end{array}$ \\
\hline
\end{tabular}




\section{ACCEPTED MANUSCRIPT}

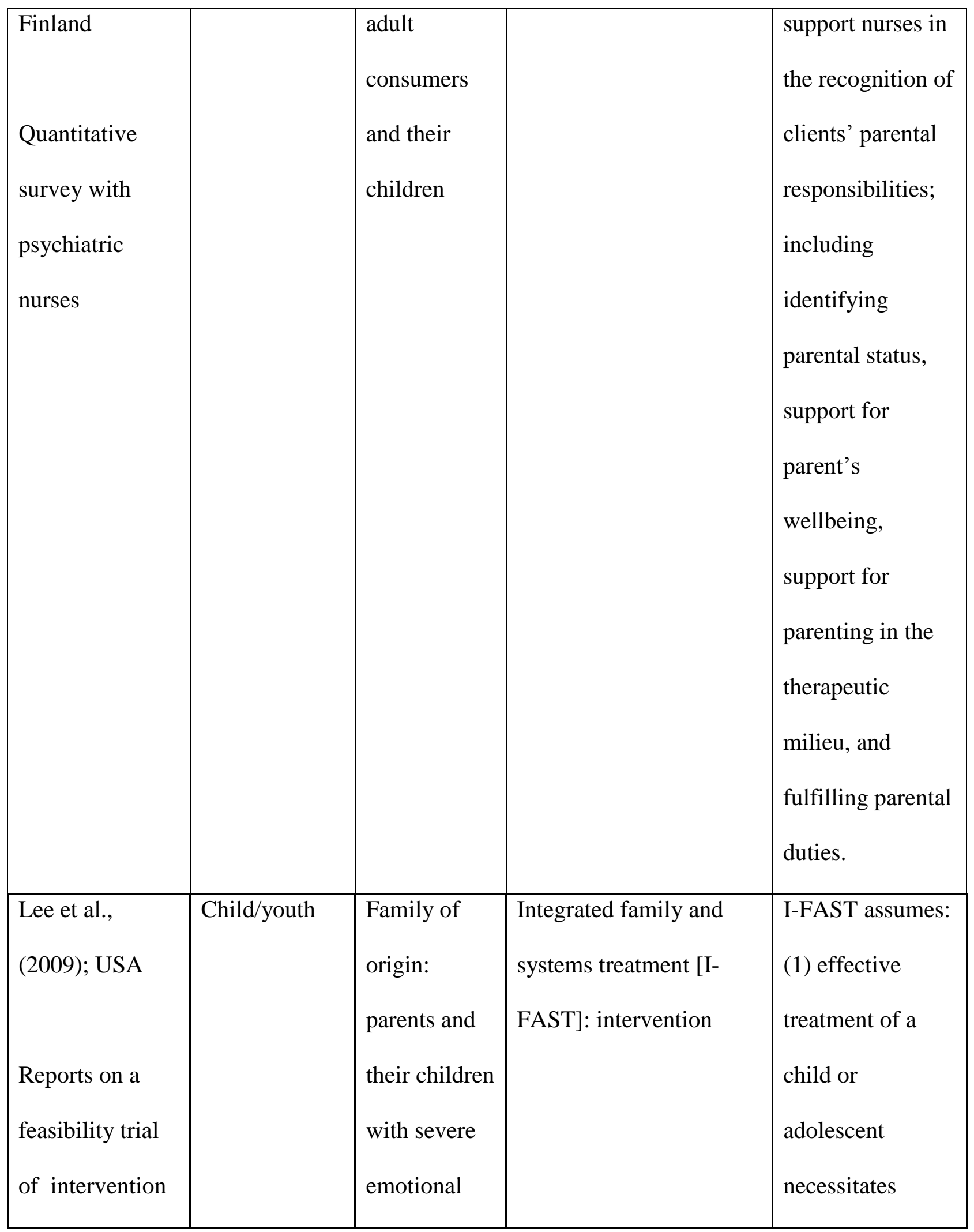




\section{ACCEPTED MANUSCRIPT}

\begin{tabular}{|c|c|c|}
\hline effectiveness & $\begin{array}{l}\text { and } \\
\text { behavioral } \\
\text { problems }\end{array}$ & $\begin{array}{l}\text { treatment of the } \\
\text { family system, } \\
\text { (2) families are } \\
\text { resilient and have } \\
\text { strengths \& } \\
\text { resources to } \\
\text { achieve client } \\
\text { change, (3) } \\
\text { effective } \\
\text { treatment must } \\
\text { treatment is built } \\
\text { include } \\
\text { effective } \\
\text { coordination and } \\
\text { child and the } \\
\text { amilaboration } \\
\text { organizations } \\
\text { providing }\end{array}$ \\
\hline
\end{tabular}




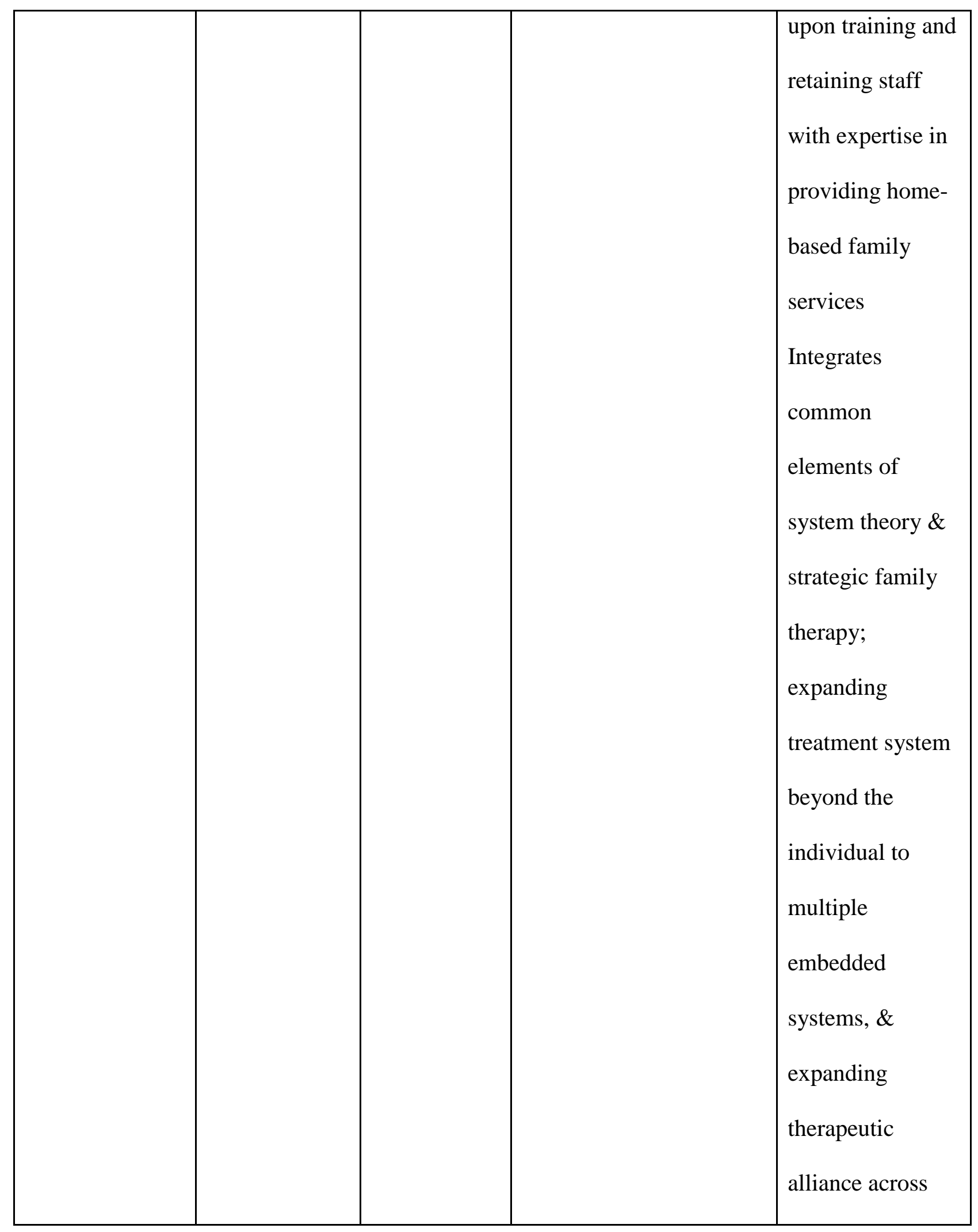




\section{ACCEPTED MANUSCRIPT}

\begin{tabular}{|c|c|c|c|c|}
\hline & & & & $\begin{array}{l}\text { numerous } \\
\text { individuals \& } \\
\text { systems }\end{array}$ \\
\hline $\begin{array}{l}\text { Lepage (2005); } \\
\text { Canada } \\
\text { Discusses two } \\
\text { interventions } \\
\text { employed in } \\
\text { rural northern } \\
\text { communities }\end{array}$ & Child/youth & $\begin{array}{l}\text { Family of } \\
\text { origin: } \\
\text { parents and } \\
\text { children } \\
\text { diagnosed s } \\
\text { with a first } \\
\text { episode } \\
\text { psychosis }\end{array}$ & $\begin{array}{l}\text { Partnership Model and } \\
\text { the Family Consultation } \\
\text { Model }\end{array}$ & $\begin{array}{l}\text { Collaboration } \\
\text { with the family's } \\
\text { local resources an } \\
\text { essential } \\
\text { component of the } \\
\text { Partnership } \\
\text { Model; as well as } \\
\text { formation of } \\
\text { complementary } \\
\text { roles between the } \\
\text { patient, the } \\
\text { family and the } \\
\text { through } \\
\text { mental health } \\
\text { professionals } \\
\text { fonsidered a rich }\end{array}$ \\
\hline
\end{tabular}




\section{ACCEPTED MANUSCRIPT}

\begin{tabular}{|c|c|c|c|c|}
\hline & & & & $\begin{array}{l}\text { resource of } \\
\text { information and } \\
\text { insight into the ill } \\
\text { member's } \\
\text { problems, as well } \\
\text { as an equal } \\
\text { partner in the } \\
\text { health care team; } \\
\text { Family } \\
\text { Consultation } \\
\text { provided on an } \\
\text { as-needed basis } \\
\text { and tailored to } \\
\text { the families' } \\
\text { specific needs, } \\
\text { learning styles } \\
\text { and time } \\
\text { schedules. }\end{array}$ \\
\hline $\begin{array}{l}\text { Maddocks et al., } \\
\text { (2010); UK }\end{array}$ & Adult & $\begin{array}{l}\text { Family of } \\
\text { procreation: } \\
\text { consumers } \\
\text { and their }\end{array}$ & $\begin{array}{l}\text { An integrated model of } \\
\text { care }\end{array}$ & $\begin{array}{l}\text { Family centred } \\
\text { care approach } \\
\text { obliges the } \\
\text { practitioner to }\end{array}$ \\
\hline
\end{tabular}




\section{ACCEPTED MANUSCRIPT}

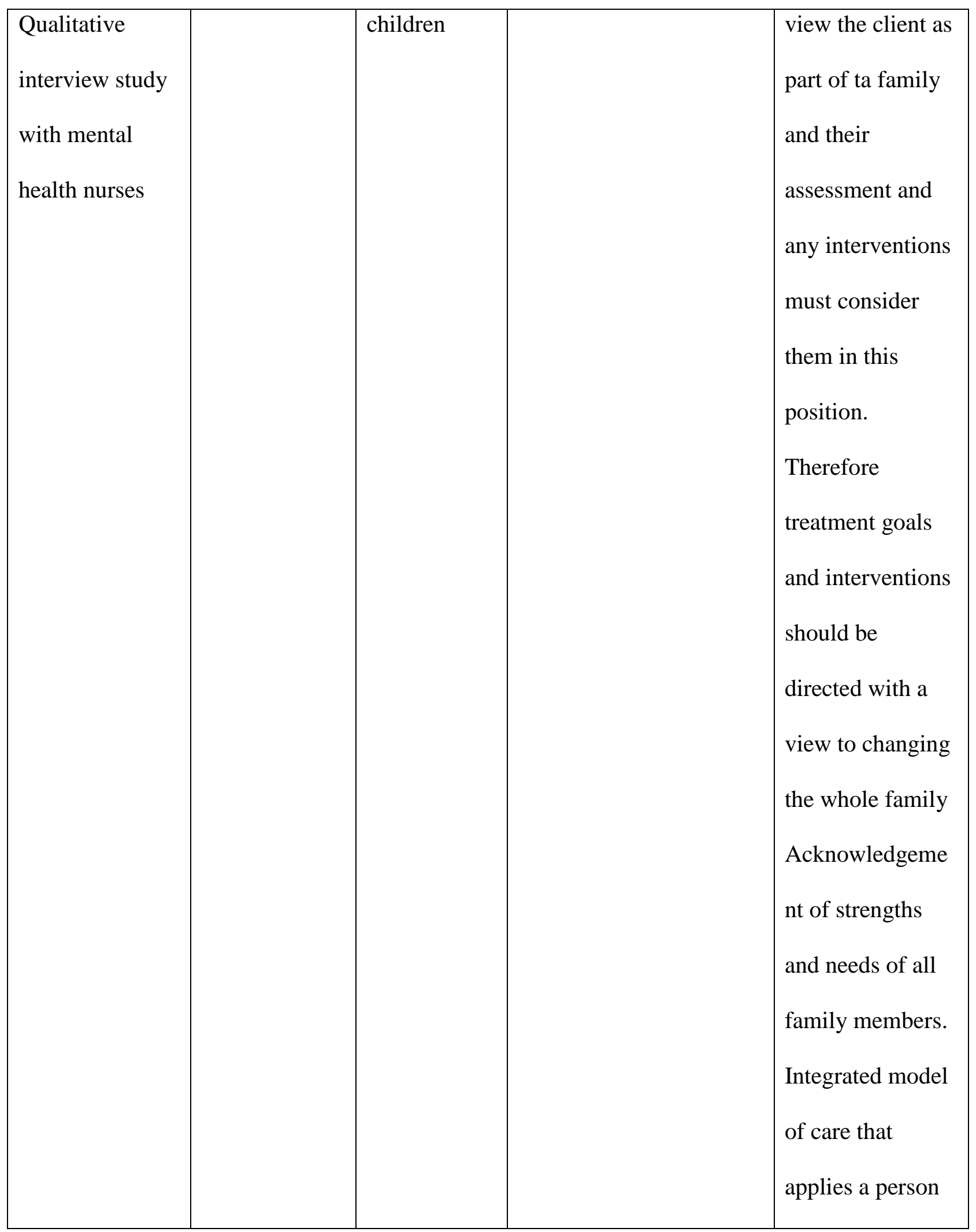




\section{ACCEPTED MANUSCRIPT}

\begin{tabular}{|c|c|c|c|c|}
\hline & & & & $\begin{array}{l}\text { centred and } \\
\text { family centred } \\
\text { approach in } \\
\text { tandem } \\
\text { Centred on } \\
\text { supporting parent }\end{array}$ \\
\hline $\begin{array}{l}\text { Malysiak } \\
\text { (1997); USA } \\
\text { Examines } \\
\text { theoretical } \\
\text { underpinnings } \\
\text { of wraparound } \\
\text { model }\end{array}$ & Child/youth & $\begin{array}{l}\text { Family of } \\
\text { origin: } \\
\text { parents and } \\
\text { their children } \\
\text { with serious } \\
\text { emotional } \\
\text { disturbance }\end{array}$ & $\begin{array}{l}\text { Wrap around model; } \\
\text { Ecological strengths } \\
\text { enhancement }\end{array}$ & $\begin{array}{l}\text { Strengths based, } \\
\text { family focused } \\
\text { ecological } \\
\text { process } \\
\text { emphasizing } \\
\text { individualized } \\
\text { services in least } \\
\text { restrictive setting } \\
\text { appropriate to } \\
\text { child's needs; } \\
\text { engaging families } \\
\text { natural strengths } \\
\text { as decision } \\
\text { making } \\
\text { participants; }\end{array}$ \\
\hline
\end{tabular}




\begin{tabular}{|l|l|l|l|l|}
\hline & & & & involvement, \\
unconditional \\
care, building \\
and maintaining \\
normative \\
(2012);
\end{tabular}




\section{ACCEPTED MANUSCRIPT}

\begin{tabular}{|c|c|c|c|c|}
\hline & & & & $\begin{array}{l}\text { responses can } \\
\text { span a broad } \\
\text { spectrum of } \\
\text { practice from } \\
\text { identifying } \\
\text { clients who are } \\
\text { parents and } \\
\text { referring to } \\
\text { relevant support } \\
\text { services to } \\
\text { providing in- } \\
\text { depth and long } \\
\text { term family } \\
\text { therapy. }\end{array}$ \\
\hline $\begin{array}{l}\text { Maybery et al. } \\
\text { (2014); } \\
\text { Australia } \\
\text { Quantitative } \\
\text { survey research } \\
\text { with variety of }\end{array}$ & Adult & $\begin{array}{l}\text { Family of } \\
\text { procreation; } \\
\text { consumers } \\
\text { and their } \\
\text { dependent } \\
\text { children }\end{array}$ & $\begin{array}{l}\text { Family focused } \\
\text { practices; } \\
\text { Family sensitive; } \\
\text { Family inclusive; } \\
\text { Family centred }\end{array}$ & $\begin{array}{l}\text { Importance of } \\
\text { collaboration } \\
\text { between } \\
\text { professionals and } \\
\text { parents and } \\
\text { families and } \\
\text { between services }\end{array}$ \\
\hline
\end{tabular}




\section{ACCEPTED MANUSCRIPT}

\begin{tabular}{|c|c|c|c|c|}
\hline $\begin{array}{l}\text { professional } \\
\text { groups }\end{array}$ & & & & \\
\hline $\begin{array}{l}\text { Miklowitz et al., } \\
\text { (2006); } \\
\text { USA } \\
\text { Discusses a } \\
\text { treatment model } \\
\text { and presents } \\
\text { data from } \\
\text { treatment study }\end{array}$ & Child/youth & $\begin{array}{l}\text { Family of } \\
\text { origin and } \\
\text { procreation: } \\
\text { parents and } \\
\text { their children } \\
\text { with early- } \\
\text { onset t } \\
\text { bipolar } \\
\text { disorder; } \\
\text { also } \\
\text { acknowledge } \\
\text { disorder } \\
\text { their own } \\
\text { may have }\end{array}$ & $\begin{array}{l}\text { Family focused } \\
\text { treatment (FFT) model }\end{array}$ & $\begin{array}{l}\text { The reciprocal } \\
\text { influences of a } \\
\text { child's biological } \\
\text { and } \\
\text { psychological } \\
\text { functioning, stage } \\
\text { of cognitive, } \\
\text { social, and } \\
\text { emotional } \\
\text { development \& } \\
\text { the family, } \\
\text { cultural, and } \\
\text { extra-familial } \\
\text { medical context } \\
\text { in which } \\
\text { symptoms are } \\
\text { expressed, } \\
\text { Need for } \\
\text { integrated } \\
\text { treatment; rely on } \\
\text { ing }\end{array}$ \\
\hline
\end{tabular}




\section{ACCEPTED MANUSCRIPT}

\begin{tabular}{|c|c|c|c|c|}
\hline & & & & $\begin{array}{l}\text { resources } \\
\text { including mental } \\
\text { health treatment, } \\
\text { extended family, } \\
\text { and community } \\
\text { supports. } \\
\text { A manualized } \\
\text { psychosocial } \\
\text { intervention } \\
\text { consisting of } \\
\text { psychoeducation, } \\
\text { communication } \\
\text { training, and } \\
\text { problem-solving } \\
\text { skills training }\end{array}$ \\
\hline $\begin{array}{l}\text { Mosier et al. } \\
\text { (2001); } \\
\text { USA } \\
\text { Discussion and } \\
\text { quantitative }\end{array}$ & Child/youth & $\begin{array}{l}\text { Family of } \\
\text { origin: } \\
\text { parents and } \\
\text { their children } \\
\text { with mental } \\
\text { health issues }\end{array}$ & $\begin{array}{l}\text { Family preservation } \\
\text { services (FPS): } \\
\text { intervention }\end{array}$ & $\begin{array}{l}\text { The rationale } \\
\text { underlying this } \\
\text { approach } \\
\text { involves having } \\
\text { treatment goals } \\
\text { driven by }\end{array}$ \\
\hline
\end{tabular}




\section{ACCEPTED MANUSCRIPT}

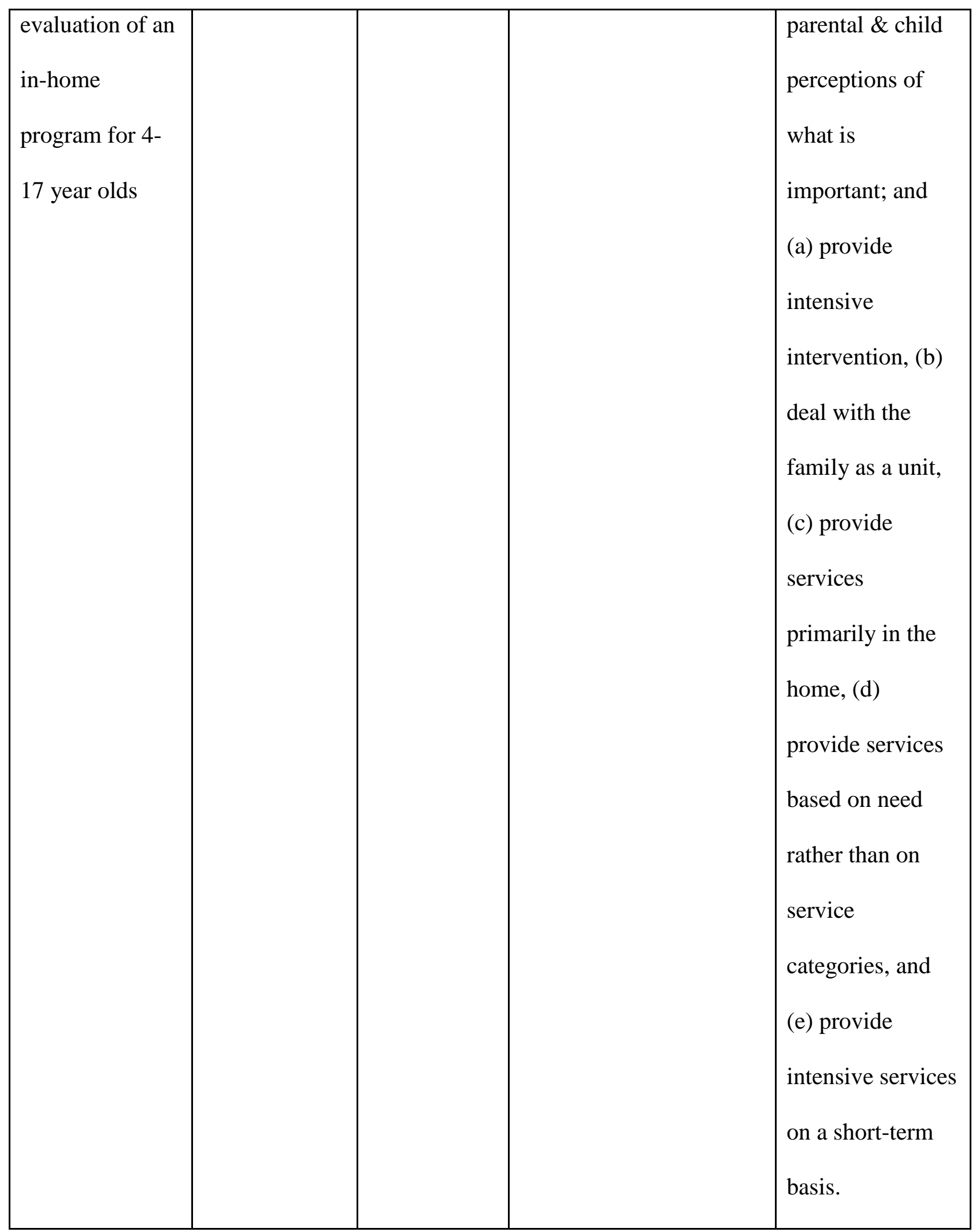




\section{ACCEPTED MANUSCRIPT}

\begin{tabular}{|c|c|c|c|c|}
\hline & & & & $\begin{array}{l}\text { FPS similar to } \\
\text { wraparound } \\
\text { principles }\end{array}$ \\
\hline $\begin{array}{l}\text { Mottaghipour \& } \\
\text { Bickerton } \\
(2005) \text {; } \\
\text { Australia } \\
\text { Theoretical } \\
\text { discussion of } \\
\text { FFP }\end{array}$ & Adult & $\begin{array}{l}\text { Family of } \\
\text { origin and } \\
\text { procreation: } \\
\text { consumers } \\
\text { and their } \\
\text { parents and } \\
\text { children }\end{array}$ & $\begin{array}{l}\text { Family work; } \\
\text { Pyramid of family care; } \\
\text { Model of family care }\end{array}$ & $\begin{array}{l}\text { Collaboration } \\
\text { with families } \\
\text { Partnership with } \\
\text { parents - } \\
\text { different levels of } \\
\text { intervention } \\
\text { negotiated over } \\
\text { varying } \\
\text { timeframes }\end{array}$ \\
\hline $\begin{array}{l}\text { Description and } \\
\text { evaluation (both } \\
\text { qualitative and }\end{array}$ & Youth & $\begin{array}{l}\text { Family of } \\
\text { origin: adults } \\
\text { of consumers } \\
\text { (young } \\
\text { adults) } \\
\text { experiencing } \\
\text { first }\end{array}$ & Family intervention & $\begin{array}{l}\text { Families play a } \\
\text { major role in } \\
\text { promoting } \\
\text { service users' } \\
\text { recovery and } \\
\text { preventing } \\
\text { relapse }\end{array}$ \\
\hline
\end{tabular}




\section{ACCEPTED MANUSCRIPT}

\begin{tabular}{|c|c|c|c|c|}
\hline $\begin{array}{l}\text { quantitative) of } \\
\text { family } \\
\text { intervention }\end{array}$ & & $\begin{array}{l}\text { psychotic } \\
\text { episode }\end{array}$ & & $\begin{array}{l}\text { Nurses have a } \\
\text { central role in } \\
\text { providing family } \\
\text { interventions } \\
\text { Early } \\
\text { intervention } \\
\text { important }\end{array}$ \\
\hline $\begin{array}{l}\text { Nicholson } \\
\text { (2007); USA } \\
\text { Discussion of } \\
\text { FFP in relation } \\
\text { to families } \\
\text { where a parent } \\
\text { has a mental } \\
\text { illness }\end{array}$ & Adult & $\begin{array}{l}\text { Family of } \\
\text { procreation; } \\
\text { consumers } \\
\text { and their } \\
\text { dependent } \\
\text { children }\end{array}$ & $\begin{array}{l}\text { Family centred; } \\
\text { Strengths based } \\
\text { approach }\end{array}$ & $\begin{array}{l}\text { Helping parents } \\
\text { can help children } \\
\text { Parenting is an } \\
\text { important and } \\
\text { fulfilling life role } \\
\text { Strengths based } \\
\text { approach (builds } \\
\text { natural supports) } \\
\text { Partnership } \\
\text { process with } \\
\text { services } \\
\text { Parents will be } \\
\text { successful if } \\
\text { given right }\end{array}$ \\
\hline
\end{tabular}




\begin{tabular}{|c|c|c|c|c|}
\hline & & & & \begin{tabular}{|l} 
supports \\
Prevention \\
important to \\
prevent or reduce \\
likelihood of \\
intergenerational \\
transmission of \\
mental illness
\end{tabular} \\
\hline $\begin{array}{l}\text { O’ Brien et al., } \\
\text { (2011); } \\
\text { Australia } \\
\text { Qualitative } \\
\text { interview study } \\
\text { with acute } \\
\text { setting staff }\end{array}$ & Adult & $\begin{array}{l}\text { Family of } \\
\text { procreation; } \\
\text { consumers } \\
\text { and their } \\
\text { dependent } \\
\text { children }\end{array}$ & $\begin{array}{l}\text { Family focused services; } \\
\text { Family friendly services }\end{array}$ & $\begin{array}{l}\text { Nurses have a } \\
\text { responsibility to } \\
\text { support and } \\
\text { understand } \\
\text { clients in their } \\
\text { parenting role as } \\
\text { part of overall } \\
\text { care }\end{array}$ \\
\hline $\begin{array}{l}\text { Pierpont \& } \\
\text { McGinty, 2004; } \\
\text { USA. }\end{array}$ & $\begin{array}{l}\text { Children \& } \\
\text { youth }\end{array}$ & $\begin{array}{l}\text { Family of } \\
\text { origin: } \\
\text { children with } \\
\text { mental } \\
\text { health issues } \\
\text { and their }\end{array}$ & $\begin{array}{l}\text { Family orientated } \\
\text { program based on } \\
\text { Systems of Care }\end{array}$ & $\begin{array}{l}\text { Child centred } \\
\text { Family focused } \\
\text { Community } \\
\text { based } \\
\text { Culturally } \\
\text { competent }\end{array}$ \\
\hline
\end{tabular}




\section{ACCEPTED MANUSCRIPT}

\begin{tabular}{|c|c|c|c|c|}
\hline $\begin{array}{l}\text { treatment } \\
\text { program }\end{array}$ & & families & & \\
\hline $\begin{array}{l}\text { Reupert \& } \\
\text { Maybery } \\
(2014) \text {; } \\
\text { Australia } \\
\text { Qualitative } \\
\text { interviews with } \\
\text { mental health } \\
\text { practitioners }\end{array}$ & Adult & $\begin{array}{l}\text { Family of } \\
\text { procreation; } \\
\text { consumers } \\
\text { and their } \\
\text { children }\end{array}$ & $\begin{array}{l}\text { Family sensitive practice } \\
\text { or approach }\end{array}$ & $\begin{array}{l}\text { Strengths based } \\
\text { approach } \\
\text { Partnership } \\
\text { between parents } \\
\text { and practitioners } \\
\text { pivotal } \\
\text { Families have } \\
\text { complex needs so } \\
\text { need for } \\
\text { interagency co- } \\
\text { operation } \\
\text { parents, children } \\
\text { Feed to balance } \\
\text { pamily sensitive } \\
\text { competing needs } \\
\text { of children \& } \\
\text { parents } \\
\text { important given } \\
\text { theeds of } \\
\text { paces }\end{array}$ \\
\hline
\end{tabular}




\section{ACCEPTED MANUSCRIPT}

\begin{tabular}{|c|c|c|c|c|}
\hline & & & & $\begin{array}{l}\text { \& wider family } \\
\text { FFP can stop or } \\
\text { reduce } \\
\text { intergenerational } \\
\text { transmission of } \\
\text { mental illness }\end{array}$ \\
\hline $\begin{array}{l}\text { Schmidt \& } \\
\text { Monaghan } \\
(2012) \text {; } \\
\text { USA } \\
\text { Description of } \\
\text { family support } \\
\text { service }\end{array}$ & Adult & $\begin{array}{l}\text { Family of } \\
\text { origin and } \\
\text { family of } \\
\text { procreation }\end{array}$ & $\begin{array}{l}\text { Intensive family support } \\
\text { service }\end{array}$ & $\begin{array}{l}\text { Structures of } \\
\text { service driven by } \\
\text { individual family } \\
\text { choice } \\
\text { Collaborative } \\
\text { process based on } \\
\text { trust } \\
\text { Focus of } \\
\text { intervention is } \\
\text { determined by } \\
\text { the family's } \\
\text { concerns } \\
\text { Strengths based } \\
\text { competence of } \\
\text { family }\end{array}$ \\
\hline
\end{tabular}




\section{ACCEPTED MANUSCRIPT}

\begin{tabular}{|c|c|c|c|c|}
\hline & & & & $\begin{array}{l}\text { Promotes } \\
\text { recovery }\end{array}$ \\
\hline $\begin{array}{l}\text { Sin et al. } \\
\text { (2007); UK } \\
\text { Discusses the } \\
\text { process for } \\
\text { developing a } \\
\text { service for } \\
\text { carers of a } \\
\text { young adult } \\
\text { with first } \\
\text { episode } \\
\text { psychosis }\end{array}$ & Child/youth & $\begin{array}{l}\text { Family of } \\
\text { origin: } \\
\text { parents and } \\
\text { their youth } \\
\text { with early } \\
\text { onset } \\
\text { psychosis }\end{array}$ & $\begin{array}{l}\text { Early Intervention in } \\
\text { Psychosis service }\end{array}$ & $\begin{array}{l}\text { Services } \\
\text { developed to } \\
\text { address carers' } \\
\text { needs for } \\
\text { knowledge, skills } \\
\text { and support to } \\
\text { cope with their } \\
\text { caring roles \& } \\
\text { situation, from } \\
\text { stressful } \\
\text { beginnings of a } \\
\text { potentially long } \\
\text { caring journey }\end{array}$ \\
\hline $\begin{array}{l}\text { Discusses } \\
\text { intensive in- }\end{array}$ & Child/youth & $\begin{array}{l}\text { Family of } \\
\text { origin: } \\
\text { parents and } \\
\text { their children } \\
\text { with severe }\end{array}$ & $\begin{array}{l}\text { The Intensive In-Home } \\
\text { Child \& Adolescent } \\
\text { Psychiatric Service } \\
\text { (IICAPS): approach }\end{array}$ & $\begin{array}{l}\text { Combines } \\
\text { elements of } \\
\text { medicalized } \\
\text { treatment with } \\
\text { system-of-care }\end{array}$ \\
\hline
\end{tabular}




\begin{tabular}{|c|c|c|c|c|}
\hline $\begin{array}{l}\text { home } \\
\text { child/youth } \\
\text { family-focused } \\
\text { approach. }\end{array}$ & & $\begin{array}{l}\text { emotional } \\
\text { disturbances }\end{array}$ & & $\begin{array}{l}\text { principles that } \\
\text { place a high } \\
\text { value on } \\
\text { authentic parent } \\
\text { involvement and } \\
\text { attention to youth } \\
\text { and family } \\
\text { strengths; } \\
\text { Focus on four } \\
\text { critical domains: } \\
\text { child, family, } \\
\text { school \& } \\
\text { areatment } \\
\text { environment, and } \\
\text { other systems } \\
\text { Family members } \\
\text { all aspects of } \\
\text { trensidered }\end{array}$ \\
\hline $\begin{array}{l}\text { Young \& } \\
\text { Fristad, (2007); } \\
\text { USA }\end{array}$ & Child/youth & $\begin{array}{l}\text { Family of } \\
\text { origin: } \\
\text { children with }\end{array}$ & $\begin{array}{l}\text { Four programs } \\
\text { presented: Family- } \\
\text { focused treatment (FFT); }\end{array}$ & $\begin{array}{l}\text { Describes four } \\
\text { programs based } \\
\text { upon a }\end{array}$ \\
\hline
\end{tabular}




\section{ACCEPTED MANUSCRIPT}

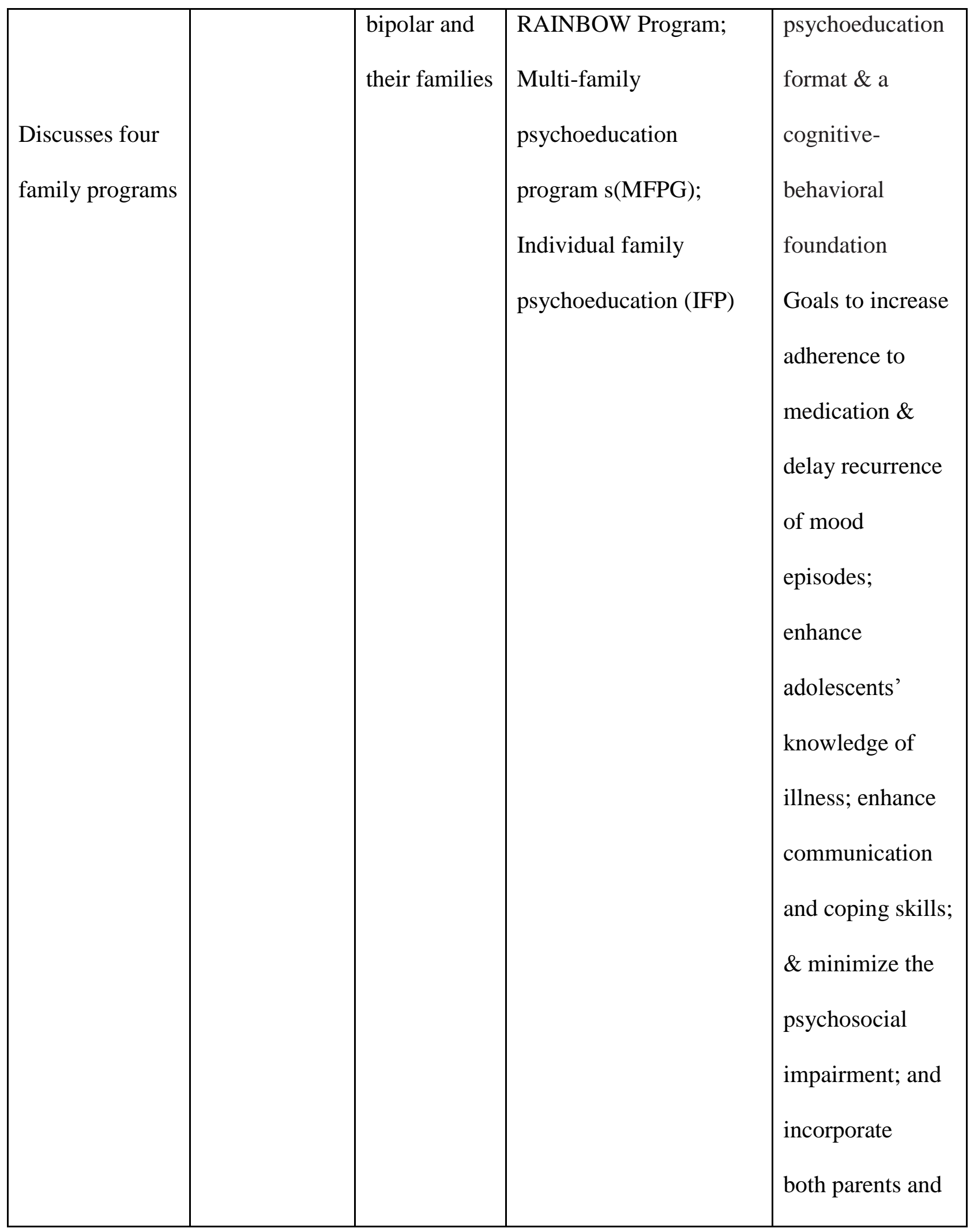




\section{ACCEPTED MANUSCRIPT}

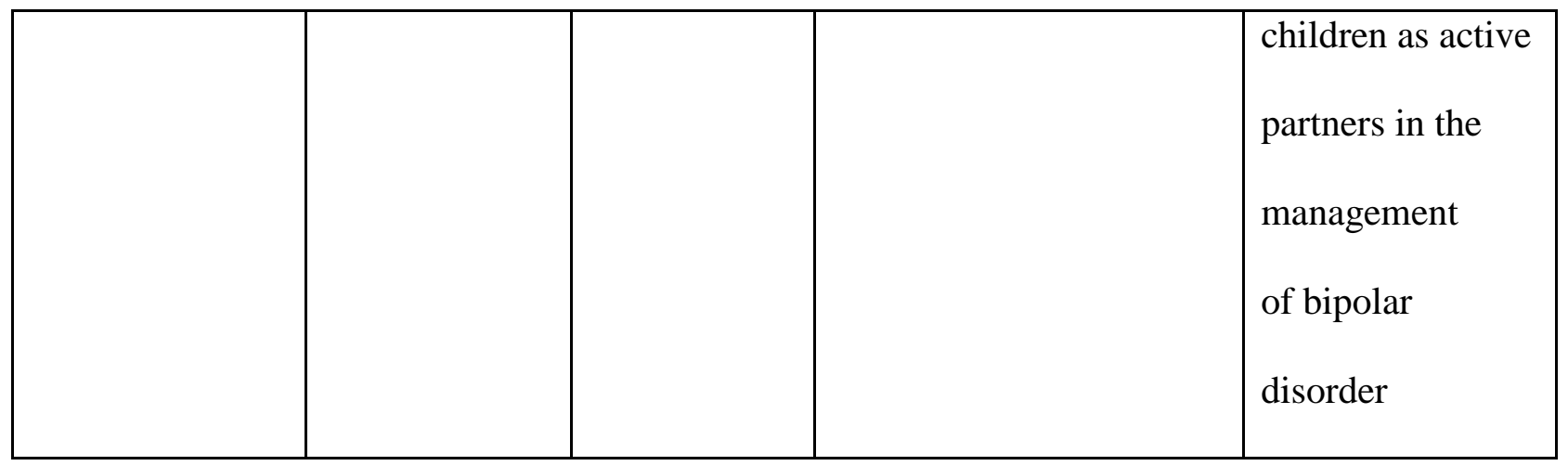




\section{ACCEPTED MANUSCRIPT}

Table 3: Family-focused core and inter-related practices and descriptions

\begin{tabular}{|c|c|}
\hline Core practice & Description \\
\hline $\begin{array}{l}\text { 1. Family care planning \& } \\
\text { goal setting }\end{array}$ & $\begin{array}{l}\text { Clinicians conduct care planning including } \\
\text { collaboratively establishing crisis/care plans with } \\
\text { families and assisting family members to set goals both } \\
\text { in relation to the individual's recovery and also in } \\
\text { relation to improving family members' mental health } \\
\text { and wellbeing. }\end{array}$ \\
\hline $\begin{array}{l}\text { 2. Liaison between family } \& \\
\text { services including } \\
\text { advocacy }\end{array}$ & $\begin{array}{l}\text { Liaison between families and services. Advocacy } \\
\text { involves acting, speaking or encouraging actions with } \\
\text { services to achieve better outcomes for families. }\end{array}$ \\
\hline $\begin{array}{l}\text { 3. Instrumental, emotional } \\
\text { \& social support }\end{array}$ & $\begin{array}{l}\text { Instrumental support involves the clinician referring a } \\
\text { family member to another service, and organising } \\
\text { practical support e.g. transport or child-care. } \\
\text { Emotional support involves showing empathy and } \\
\text { compassion to family members. Social support } \\
\text { involves empowering families and encouraging } \\
\text { individuals and families to expand social networks and } \\
\text { improve their connections with others. }\end{array}$ \\
\hline
\end{tabular}




\section{ACCEPTED MANUSCRIPT}

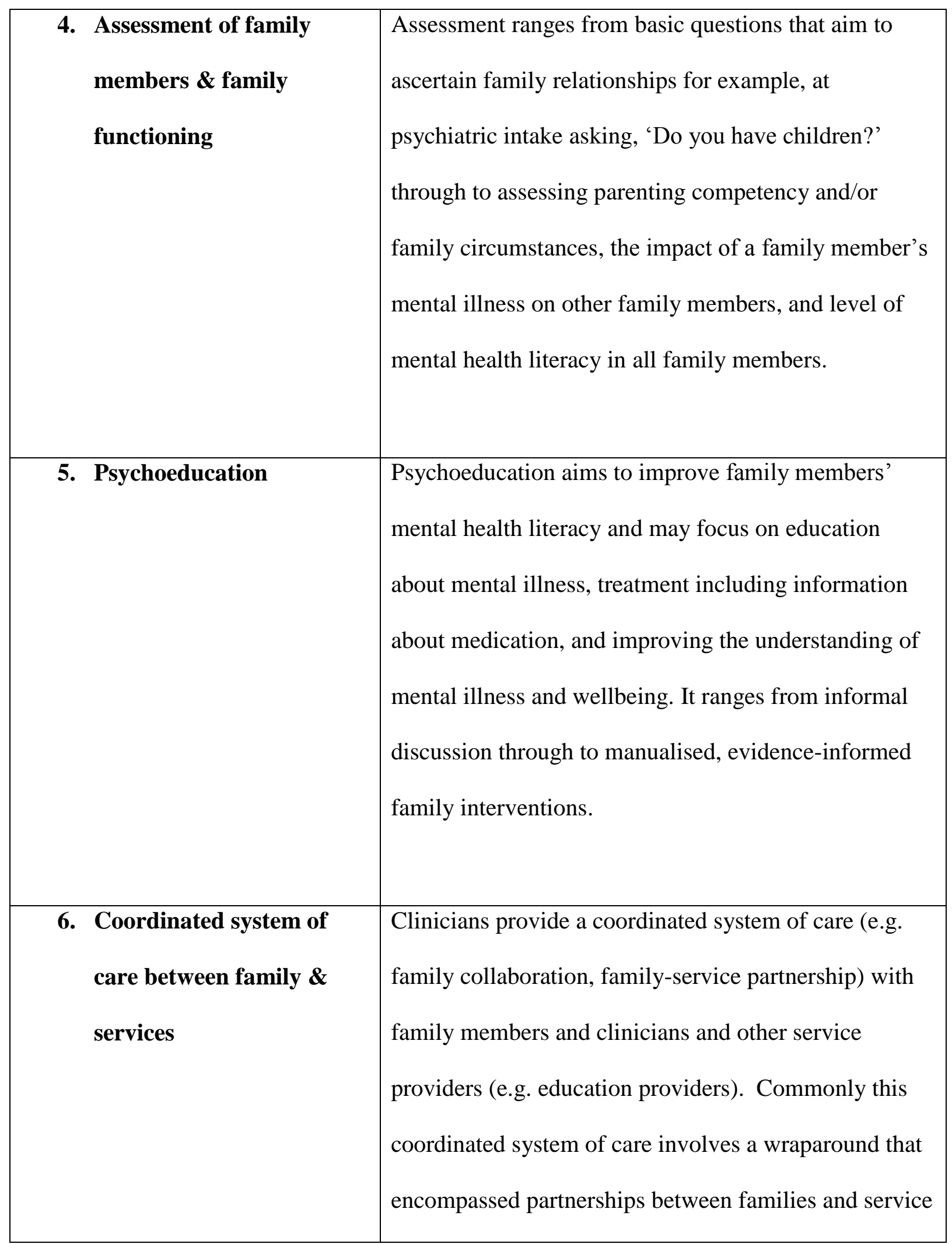




\section{ACCEPTED MANUSCRIPT}

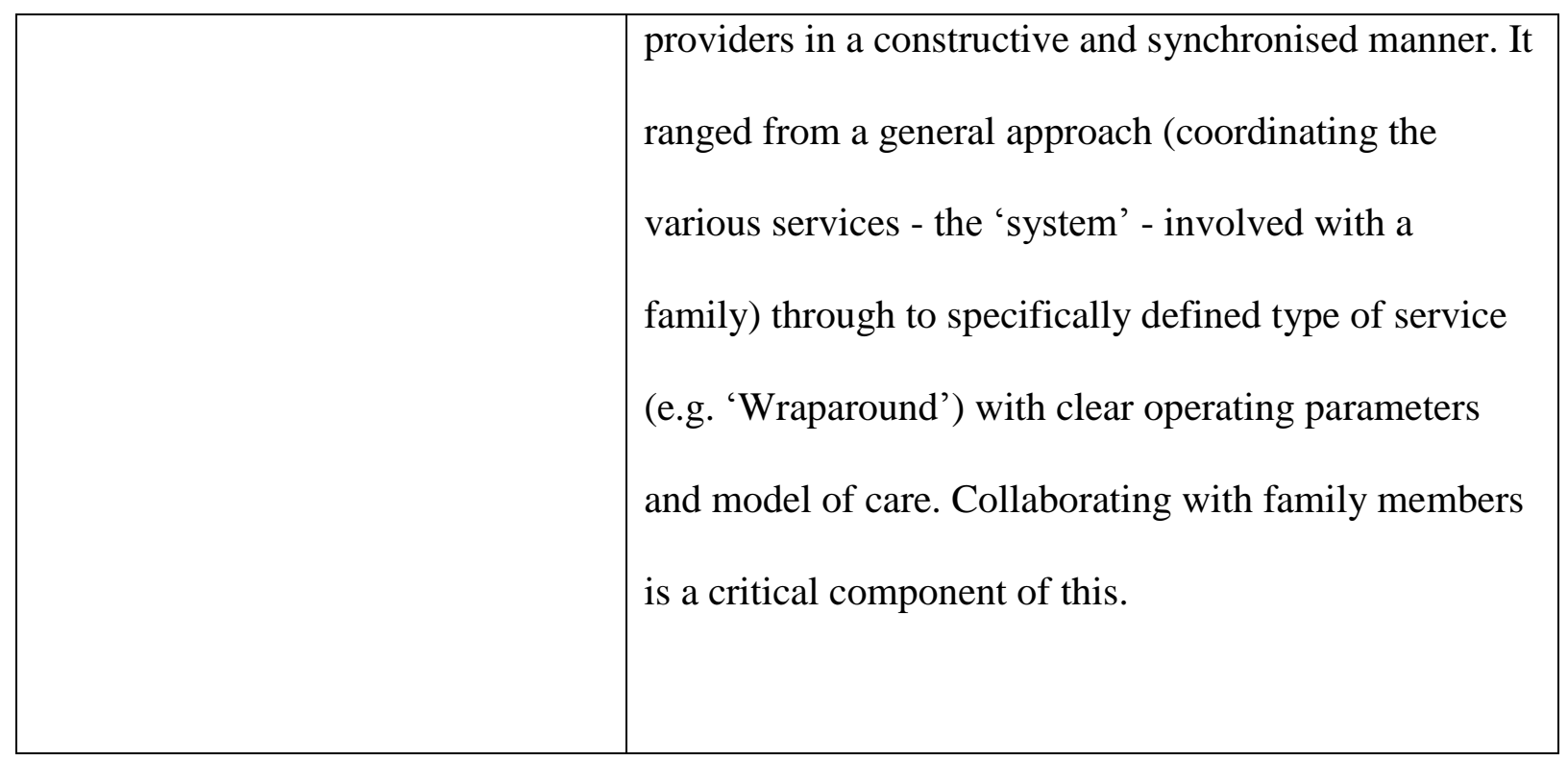

